\title{
Of Fine Lines, Blunt Instruments, and Half-Truths: Business Acquisition Agreements and the Right to Lie
}

\author{
Jeffrey M. Lipshaw*
}

\footnotetext{
*Visiting Professor, Tulane University Law School; Associate Professor, Suffolk University Law School (offer accepted; appointment effective July 1, 2007 pending). This article stems from a blog discussion on Conglomerate among Gordon Smith, Frank Snyder, and me from February 28, 2006 to March 3, 2006. See Gordon Smith, Contracting to Lie, CONGLOMERATE, available at http://www.theconglomerate.org/ 2006/02/contracting_to_.html (last visited, Apr. 29, 2006). I appreciate comments on the thesis from Professors Smith and Snyder, as well as from Larry Solum and Alan Palmiter. I also appreciate comments and questions during presentations of this thesis in faculty colloquia at Suffolk Law School, Tulane Law School, Texas Wesleyan University Law School, Thomas Jefferson Law School, Marquette University Law School, and South Texas College of Law. In particular, I am indebted to Professor Arnold Rosenberg for honing the union certification hypothetical
} 


\begin{abstract}
In this article, I expand upon a happy coincidence (for scholars) in reconciling the overlap between contract and fraud. Both the recent book by Ian Ayres and Gregory Klass and the Delaware Court of Chancery in Abry Partners Acquisition V, L.P. v. F\& $W$ Acquisition, $L L C$ addressed the issue of promissory fraud - the making of a contract as to which the promisor had no intention of performing. Each treatment, however, in focusing on fraudulent affirmative representations, falls short of (a) recognizing the fundamental aspect of deceptive promising in a complex deal, namely the half-truth, (b) articulating an appropriate doctrinal principle to address it, or (c) capturing the social and linguistic context that makes the deceptive half-truth so insidious.

The archetypal facts in Abry frame the issue. When the parties to a business acquisition agreement purport to limit the buyer's reliance to those representations and warranties set forth in the agreement, just what obligations of truth-telling have the parties contractually released? We need to grapple with the inter-relationship of law, language, mutual understanding, and trust. The language of the law (and the contract) is a blunt instrument by which to map to track the subtle fine lines of a complex agreement. I will contend that there is a kind of special arrogance in the illusion onto which lawyers hold - that the uncertainties and contingencies of the world are in their power to be controlled, and to the winner of the battle of words go the spoils. The correct doctrinal result is to presume in the transactional speech acts (including the contract), as we do in everyday life, a default of truth-telling, to permit the parties freely to contract around the rule, but to require narrow construction of the exceptions and disclaimers.
\end{abstract}




\section{TABLE OF CONTENTS}

I. Introduction

II. The Case
A. The Context of Private Equity
B. The Deal
1. The Set-up
2. The Buyer and the Contract
3. The Shenanigans
C. The Denouement and the Claims

III. The Critique
A. The Doctrinal Critique
1. The Source of the Problem
2. A Doctrinal Alternative
B. The Theoretical Critique
1. Restating the Problem
2. An Efficiency Critique
3. A Linguistic and Social Critique
a. Presumptions Based on the Use of Language and the Warranties of Speech Acts
b. Disclaimers of Truth-Telling as Social Phenomenon
(1) The Lawyer's Constitutive View of Contracts
(2) Contracts and Trust

IV. Conclusion 


\section{INTRODUCTION}

The parties to sophisticated business acquisitions use a number of methods to assure themselves of an appropriate allocation of risk. Sellers provide buyers an opportunity for due diligence; buyers undertake their own investigation apart from the resources made available by sellers; the parties adjust the price to reflect risks; and the parties use the language of contracts seemingly to provide a final statement of the rights and obligations of one to the other. Yet those methods do not wholly dispose of postagreement disputes. Whether a matter of opportunism or a matter of interpretation (or one disguised as the other), buyers still sue sellers, even where each is sophisticated and relied on expert legal, accounting, operational, and transactional counsel.

The line in our jurisprudence between contract law and tort law becomes all the more visible where these same sophisticated parties attempt to use the language of contract to set the bounds of the seller's obligation to share information. Combined with contractual language limiting the seller's liability for breaches of covenants, warranties, and representation, there can be an intended or unintended over-inclusiveness. Did the parties intend, or should they be presumed to have intended, to have those provisions limit seller's liability for intentional misrepresentation of the state of the business?

There have been two recent and highly sophisticated treatments on the question of promissory fraud, one academic and one judicial, in recent months. Ian Ayres and Gregory Klass have published Insincere Promises: The Law of Misrepresented Intent. ${ }^{1}$ The authors seek to fill the gap into which the cause of action for promissory fraud falls being something beyond the scope of the contract law syllabus, but something not

\footnotetext{
${ }^{1}$ IAN Ayres \& GREgory Klass, Insincere Promises: The LAW of MisRePresented IntENT (2006).
} 
addressed in the torts class. Their subject is the relationship between liability for the nonperformance of a promise, and the liability where not only was the promise not performed, but the promisor never intended to perform from the outset. The proposed legal approach recognizes the complexity (and non-reducibility) of the world. Law ultimately is neither natural nor social science, and cannot be reduced to algorithms. It is instead a social structure in which we come to agree that certain actions, even as between private parties, are worthy of sanction through the legal process. As a reflection of an "anti-reductionist approach to the theory of promising - which refuses to pack every aspect of the transaction into the duty to perform," ${ }^{2}$ Ayres and Klass argue for the retention in the law of a doctrine by which the making of a promise without the intention to perform is separately actionable under the law of fraud.

In Abry Partners V, L.P. v. F\&W Acquisition, LLC, ${ }^{3}$ Vice-Chancellor Leo Strine of the Delaware Court of Chancery found himself presiding over a real-world allegation of promissory fraud. The issue was whether the fairly typical indemnity cap and exclusive remedy clause in a business acquisition agreement barred an extra-contractual fraud remedy where the allegation was the seller knew one of the contractual representations to be false. The court held that the parties intended to limit liability even for deliberate falsehood, but such limitation was not enforceable as a matter of public policy in Delaware. The immediate academic reaction centered on whether one can disclaim the obligation to tell the truth, with the general consensus being: yes, it is a dogeat-dog formalistic world out there. Professor Larry Ribstein criticized the opinion along

\footnotetext{
${ }^{2} I d$. at 204 .

3891 A.2d 1032 (Del. Ch. 2006).
} 
those lines on his blog. ${ }^{4}$ Professor Frank Snyder suggested, in the same vein, that sophisticated parties, having agreed to this kind of disclaimer, should be obliged to provide an explicit provision if they want to be protected against lying. ${ }^{5}$

These are admirable advances in consideration this area of the law, which heretofore has received scant treatment. ${ }^{6}$ But each, in my view, tantalizes but falls short in different ways, but each in truncating the inquiry, perhaps by oversimplifying the problem presented. The common focus of the book and the case are the legal implications of a speech act that falsely represents something known to the speaker; in the book, that information is the speaker's undisclosed intention not to perform the promise, and in the case, it is the speaker's failure to disclose the true condition of the business. I believe Ayres and Klass have gotten closer to the essence of the problem the implicit warranties in the very use of language. But each treatment sees lying merely as a false statement, and the art of deception is far more nuanced.

The publication of the book and the issuance of the Abry opinion are a happy coincidence. The facts presented in Abry - the deal, the contract, the due diligence, even the shenanigans that provoked the post-closing lawsuit - are an archetype. Its appeal as grist for the scholarly mill lies not in its idiosyncrasy but in its very typicality. Moreover, the very wealth and sophistication of both parties create a kind of jurisprudential laboratory to examine the intersection of fraud and contract. And finally, the case raises fundamental theoretical issues about a subtle truth-telling understanding among those who negotiate complex deals, and whether the power of language can be harnessed to

\footnotetext{
${ }^{4}$ Larry E. Ribstein, Should a Court Enforce a Contract That Permits Lying, IDEOBLOG, available at http://busmovie.typepad.com/ideoblog/2006/02/should_a_court_html.

${ }^{5}$ See comment of Frank Snyder to Contracting to Lie, supra note 1.

${ }^{6}$ AYRES \& KLASS, supra note 1, at 6 . The authors provide an extensive bibliography supporting this assertion at note 20 .
} 
reflect it. Each treatment, however, in focusing on fraudulent affirmative representations, falls short of (a) recognizing the fundamental aspect of deceptive promising in a complex deal, namely the half-truth, (b) articulating an appropriate doctrinal principle to address it, or (c) capturing the social and linguistic context that makes the deceptive half-truth so insidious.

If anything, this decision issued by a thoughtful and scholarly judge in a universally recognized business-friendly forum is evidence of how lawyers and judges can be seduced or even blinded by what they think is a lawyer's unique power over language. So, while I agree with the result, I will suggest, as a matter of doctrine, there is a rule of law that maps more precisely on the common understanding of participants in complex acquisitions, as well as the way in which all of us, including sophisticated deal negotiators, ordinarily expect language to be used. Moreover, while I think Ayres and Klass have captured the spirit of my thesis here, it is necessary to expand on their thinking to address fully the issues presented in Abry.

My project here is not merely to state a better doctrine by which courts should reconcile freedom of contract and the law of fraud. As Ayres and Klass correctly observe, "[p]hilosophers find it endlessly fascinating that by the mere act of uttering certain words one can create a duty for oneself. Legal thinkers are faced with the more pressing practical problem of whether, why, and how the law should take cognizance of such duties." ${ }^{, 7}$ Having criticized Vice-Chancellor Strine's holding, I am obliged to state my proposed doctrinal result. And I will suggest, as a matter of efficiency enhancing

\footnotetext{
${ }^{7} I d$., at 2 .
} 
doctrine that it follows wholly within the information-forcing default rule analysis proposed by Ayres and Klass. ${ }^{8}$

But I wish to take up the philosophical inquiry left largely untouched by those scholars. This archetypal case unpeels like an artichoke, invoking, ultimately, the interrelationship of law, language, mutual understanding, and trust. The language of the law is inadequate - a blunt instrument - by which to map track the fine lines of a complex agreement, and that requires us to go beyond the law to the psychology and philosophy of language itself. I will contend that there is a kind of special arrogance in the illusion onto which lawyers hold - that the uncertainties and contingencies of the world are in their power to be controlled, and to the winner of the battle of words go the spoils.

Vice-Chancellor Strine tried admirably to reconcile the polarities of the policy of promoting freedom of contract versus the law's adoption of a moral code (don't lie) in the law of fraud. But, it seems to me, he got lost somewhere in that illusion of the power of language, and found himself required to resort to the deus ex machina of public policy to cure what seemed to him, nevertheless, an injustice. But his solution was flawed precisely because it is a continuation of the problem: giving too much credit to the lawyers' ability to capture the affirmative essence of the deal in the contract language, and seeing the contract as the embodiment rather than a reflection of the deal. It is a kind of formalism, a "four corners" approach that fails to capture the underlying texture of the promise and its context.

That is because the law of contracts as applied here (like the Ayres and Klass analysis of misrepresented intent) only deals with affirmative misrepresentations (and reliance thereon), and does not capture that implicit context of the deal by which the

\footnotetext{
${ }^{8} I d$, at $83-112$.
} 
parties also understand that there is some duty that has been created more akin to what in the law of fraud is omission or half-truth. ${ }^{9}$ And, indeed, the essence of this case was not promissory fraud, but half-truth and omission. The contract never addressed omissions, nor, as Vice-Chancellor Strine conceded, did it ever explicitly disclaim the right of rescission on account of either intra-contractual or extra-contractual misrepresentation.

My doctrinal result is easy to state. Where, as in Abry, the parties have disclaimed reliance on extra-contractual representations, freedom of contract requires that the provision be given its precise effect. The disclaimer should only be effective in the instances either (a) where the extra-contractual representation conflicts with the contractual representation, or (b) where the contract is wholly on the subject matter of the extra-contractual representation. A disclaimer of reliance on extra-contractual representations cannot and should not be deemed to impact the half-truth or omission liability that may well be the natural consequence of having made the contractual representation. Moreover, the burden should be on the party asserting the anti-reliance clause to show that it was intended to cover anything but liability arising wholly as a result of the falsity of extra-contractual representations. ${ }^{10}$

\footnotetext{
${ }^{9}$ In fairness, the general recognition of this idea constitutes the great advancement in INSINCERE PROMISES. The book is worth the investment of time if for nothing more than this passage:

But representations of intent are also tools that promisors use to accomplish very specific tasks. Promising is a complex joint intentional activity and involves a high degree of both coordination and trust between the parties. In most cases, it takes more than the performative force of the promissory act (the creation of an obligation to do the act promised) to secure those obligations.

AYRES \& KLASS, supra note 1, at 203.

${ }^{10}$ There is one extensive academic treatment of contractual disclaimers of liability for fraud. Kevin Davis, Licensing Lies: Merger Clauses, the Parol Evidence Rule and Pre-Contractual Misrepresentations, 33 VAL. U. L. REV. 485 (1999). Vice-Chancellor Strine cited it in a footnote. 891 A.2d at 1058 n. 56.

Professor Davis' focus was somewhat different from mine. He too examined the impact of typical merger or integration clauses that would have the effect, if applied literally, of exculpating a party from fraudulent or grossly negligent statements made outside the bounds of the contract in pre-contract negotiations. But the thrust of his analysis was the interplay of contract and agency law, and he concluded that whether to
} 
What, I suspect, is more controversial is my reason for advocating this rule. In the effort to credit freedom of contract and efficiency, I think the court and commentators are saying that sophisticated deal parties must (or do) assume that everything is a lie unless it is affirmatively warranted in the contract. I believe that reverses the natural import of language among human beings, lawyers and judges included. Our very use of language carries with it a presumption of truth-telling, and that presumption is not overcome simply because lawyers are writing contracts in their own variant of the same language. It is possible to write a contract provision that wholly and expressly disclaims any obligation of truth telling or avoidance of half-truth deception. But that almost never happens. Instead, the law of fraud, combined with the pleadings requirements of particularity, provides a truth-telling safety net. This is, in the end, I suspect a broader remedy than rational actor theorists or contract formalists might want, but one that I think more accurately maps on the fine line of the understanding among the lawyers and clients in the hothouse atmosphere of an intense merger or acquisition negotiation.

In Part II, I will describe the Abry opinion, primary because it reflects an archetypal deal from which generalization is possible. Part III is a critique of the doctrine analysis, and proposes a doctrinal alternative. In Part IV, I justify the alternative through an efficiency analysis akin to that proposed by Ayres and Klass. But I also take up a

enforce the disclaimer might turn on whether the party seeking to enforce the disclaimer was a natural person who was the perpetrator of the fraud, or an enterprise seeking to protect itself from its own overzealous agents. Davis, supra, at 533-34.

My project is different: to focus particularly on the limits of the ability to disclaim truth-telling among sophisticated parties. But Professor Davis' introductory quotation from Joel Feinberg captures my opening empirical intuition:

Not even in the business world -- that one area of social life where the "battle of wits" competitive-game model is most persuasive, and people match the shrewdness of their judgments and the cleverness of their stratagems for getting the better of one another -- not even here do rivals voluntarily assume the risk that the other party to an agreement is an outright liar, getting the better of one by plain deceit.

3 JOEL FEINBERG, THE MORAL LIMITS OF THE CRIMINAL LAW: HARM TO SELF 285 (1984). 
subject wholly unaddressed in the court's opinion, and alluded to but not unpacked in Insincere Promises: the reasons why, as a matter of the psychology and philosophy of language (drawing on Wittgenstein and Habermas), as well as the place the law sits in relation to everyday life (drawing on the work of Austin Sarat and Thomas Kearns), the language of contract cannot fully map on the complexity of the world, and why as a result we ought to continue to credit in the law the warranties of truthfulness inherent in language through a presumption that the remedy for half-truth fraud exists unless expressly and clearly disclaimed.

\section{THE CASE}

The facts of the case reflect the usual complexity and multiplicity of parties in private equity acquisitions, but the core allegations underlying the legal issue are relatively simple. I am going to spend some pages describing the facts, because ultimately I will turn to theory, and grounding it in these archetypal circumstances of a dispute will be helpful in bridging theory and the real world.

\section{A. The Context of Private Equity}

Private equity firms are generally in the business of buying and selling target companies, with the idea that the original cost to purchase, plus any additional investment, will be less than the proceeds upon resale of the company to a so-called strategic buyer, another private equity firm, or to the public in an initial public offering. ${ }^{11}$

Valuation of companies for purposes of mergers and acquisition players is an art and science. Although finance theory says that the value of a company is always equal to the present value of its future cash streams, the fact that the exercise is a prediction

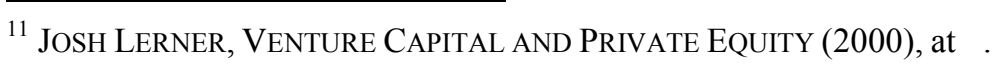


necessitates the use of estimates and heuristics. ${ }^{12}$ The particular heuristic in the publishing business was that publishing companies should sell for ten times a financial calculation called EBITDA, earnings before interest, taxes, depreciation, and amortization. ${ }^{13}$ EBITDA is often used as a surrogate for operating cash flow, ${ }^{14}$ and the applying a multiplier is an easy rule of thumb that incorporates risk and relative profitability of an industry.

B. The Deal

\section{The Set-up}

Providence Equity Partners ("Sellers" or "S”) was a private equity firm. S had purchased a company called F\&W Publishing (“Target”), which was in the book and magazine publication and distribution business. At a certain point, it decided it wanted to sell Target and embarked on the usual merger and acquisition deal process. S controlled the process, but it was Target's management, who had no previous affiliation with $\mathrm{S}$, that knew the ins and outs of the company. ${ }^{15} \mathrm{~S}$ announced publicly that it would sell Target through an auction conducted by Credit Suisse First Boston ("CSFB"), an investment banking firm, which began contacting and meeting potential buyers. ${ }^{16}$ Although the case does not say so explicitly, there can be little doubt that CSFB coordinated due diligence: plant tours, document rooms, management presentations, financial records for potential buyers.

2. The Buyer and the Contract

${ }^{12} I d .$, at $161-201$.

${ }^{13} 891$ A.2d at 1038.

14 "EBITDA," Investorwords.com, available at http://www.investorwords.com/1632/EBITDA.html.

${ }^{15} I d$., at 1037 .

${ }^{16} I d$., at 1038 . 
Abry Partners ("Buyer" or "B") was one of the suitors for Target. It participated in the usual due diligence. In parallel, it entered into contract negotiations with $\mathrm{S}$. The typically lengthy acquisition agreement had six critical provisions.

- In the main body of the agreement, Target, and not S, made the contractual representations and warranties about the condition of Target's business. But the agreement also required $\mathrm{S}$ to certify to the accuracy of the representations and warranties in the contract, which had the effect of making $\mathrm{S}$ a direct obligor on those provision. ${ }^{17}$

- As is customary, Seller warranted that the financial statements fairly represented the financial condition of Target in all material respects. ${ }^{18}$

- There were two variants of relatively common provisions under which the buyer disclaims any reliance other than on the representations and warranties set forth in the agreement. ${ }^{19}$

\footnotetext{
${ }^{17} 891$ A.2d at 1043. Vice-Chancellor Strine focuses on the distinction between the primary source of the representations, Target itself, versus the later provision in the agreement whereby $\mathrm{S}$ agreed "to put its wallet behind the Company's representations and warranties to a defined extent." I think his purpose was to show the closely-negotiated nature of S's contractual obligation, but, for my purposes, I do not see a significant point in the way the deal was structured. $\mathrm{S}$ was bound to the representations and warranties as thoroughly as if it had made them in the first instance.

${ }^{18}$ The financial representation stated:

The Company Financial Statements: (i) are derived from and reflect, in all material respects, the books and records of the Company and the Company Subsidiaries; (ii) fairly present in all material respects the financial condition of the Company and the Company Subsidiaries at the dates therein indicated and the results of operations for the periods therein specified; and (iii) have been prepared in accordance with GAAP applied on a basis consistent with prior periods except, with respect to the unaudited Company Financial Statements, for any absence of required footnotes and subject to the Company's customary year-end adjustments.

891 A.2d at 1041-42.

${ }^{19}$ Section 3.23 of the contract stated:
}

EXCEPT AS EXPRESSLY SET FORTH IN THIS ARTICLE III, THE COMPANY MAKES NO REPRESENTATION OR WARRANTY, EXPRESSED OR IMPLIED, AT LAW OR IN EQUITY IN RESPECT 
- The indemnity provision provided that $\mathrm{S}$ would be liable for damages that "...

have arisen out of or ... have resulted from, in connection with, or by virtue of the

facts or circumstances (i) which constitute an inaccuracy, misrepresentation,

breach of, default in, or failure to perform any of the representations, warranties

or covenants given or made by the Company or the Selling Stockholder in this

Agreement."20

- But S's obligation to indemnify was to be limited to a $\$ 20$ million indemnity fund that was to be "the sole and exclusive remedies of the Acquiror, the Acquiror Indemnified Persons, the Selling Stockholder, and the Company with respect to this Agreement and the Sale contemplated hereby. . ..,21

\footnotetext{
OF THE COMPANY OR THE COMPANY SUBSIDIARIES, OR ANY OF THEIR RESPECTIVE ASSETS, LIABILITIES OR OPERATIONS, INCLUDING WITH RESPECT TO MERCHANTABILITY OR FITNESS FOR ANY PARTICULAR PURPOSE, AND ANY SUCH OTHER REPRESENTATIONS OR WARRANTIES ARE HEREBY EXPRESSLY DISCLAIMED. ACQUIROR HEREBY ACKNOWLEDGES AND AGREES THAT, EXCEPT TO THE EXTENT SPECIFICALLY SET FORTH IN THIS ARTICLE III, THE ACQUIROR IS ACQUIRING THE COMPANY ON AN "AS IS, WHERE IS" BASIS. THE DISCLOSURE OF ANY MATTER OR ITEM IN ANY SCHEDULE HERETO SHALL NOT BE DEEMED TO CONSTITUTE AN ACKNOWLEDGEMENT THAT ANY SUCH MATTER IS REQUIRED TO BE DISCLOSED. Id., at 1042. In addition, Section 7.8 provided: Acquiror acknowledges and agrees that neither the Company nor the Selling Stockholder has made any representation or warranty, expressed or implied, as to the Company or any Company Subsidiary or as to the accuracy or completeness of any information regarding the Company or any Company Subsidiary furnished or made available to Acquiror and its representatives, except as expressly set forth in this Agreement ... and neither the Company nor the Selling Stockholder shall have or be subject to any liability to Acquiror or any other Person resulting from the distribution to Acquiror, or Acquiror's use of or reliance on, any such information or any information, documents or material made available to Acquiror in any "data rooms," "virtual data rooms," management presentations or in any other form in expectation Id., at 1041 . of, or in connection with, the transactions contemplated hereby.

${ }^{20} I d$., at 1044.

${ }^{21} I d$. The exclusive remedy provision did permit a claim for specific performance and injunctive relief if $\mathrm{S}$ or Target failed to comply with the contractual covenants.
} 
The upshot was that B purchased Target for $\$ 500$ million, but limited itself to $\$ 20$ million in damages for breach of contract.

\section{The Shenanigans}

As is typical in the sale of portfolio companies by private equity firms, not only

did S's management direct the sale process, but it set the financial parameters and

expectation for the sale. What is critical here is the allegation that $\mathrm{S}$ had already

determined it wanted to derive a purchase price for Target in excess of $\$ 500$ million,

necessitating, given the industry value heuristic, that the financial statement show

EBITDA of at least $\$ 50$ million. ${ }^{22}$ B alleged, ultimately, that $\mathrm{S}$ had undertaken at least

four different deceptive manipulations and non-disclosures to support the purchase price:

(1) overstating its revenues through a practice known as "backstarting,"23 (2)

underestimating reserves for book returns and uncollectible accounts, ${ }^{24}$ (3) "stuffing the channel, ${ }^{, 25}$ and (4) misrepresenting the implementation of an order entry system. ${ }^{26}$

C. The Denouement and the Claim

${ }^{22} I d$.

${ }^{23}$ One of the attractive features of a subscription-based business is that the firm takes in cash before it has to perform. To over-simplify, if a subscriber pays $\$ 300$ for a three-year subscription, under generally accepted accounting principles, the cash received may be counted in cash flow statements, but it may not be called revenue for income statement purposes until the company earns it by sending out a magazine. The allegation here was that $\mathrm{S}$ caused Target to inflate its revenues by sending back issues of the magazines upon subscription, and counting those as earned. Id.

${ }^{24}$ Book return reserves are a cost on the income statement. If the company deliberately underestimates them, it will show higher earnings.

25 "Channel stuffing" may or may not be a misstatement of the financial statements themselves, although B alleged this as another way in which book returns were underestimated. Even in the absence of a contemplated sale, a company may try to increase its reported earnings in a given period by offering terms to customers that make it attractive to buy in current rather than future reporting periods. As an example, management may perceive that fourth quarter earnings are going to fall short, and will offer discounts or extended payment terms. Even with such discounts or terms, if the products are shipped before the end of the period, they may be counted legitimately as sales revenue. Often, however, there is an adverse impact on revenue in the next quarter, because customers have all they need. Where the business is being sold as of the end of such a reporting period, a buyer may take the revenue numbers for the current period as indicative of annualized sales, and discover only after closing that the practice caused them to be inflated. Id. at 1039 .

${ }^{26} I d$., at $1039-40$. 
After the closing, B discovered the various shenanigans, and concluded that it had paid $\$ 500$ million for a business that was fairly worth $\$ 400$ million. ${ }^{27}$ B claimed that $\mathrm{S}$ and the management of Target had together manipulated Target's financial statements to induce B to buy Target at an excessively high price. Accordingly, B alleged not only that the usual financial representations and warranties in the agreement were false, but that $\mathrm{S}$ had defrauded B by knowingly making false representation within the contract and outside of the contract in the course of due diligence.

No doubt frustrated by the $\$ 20$ million damage cap it negotiated on a $\$ 500$ million purchase, B sought rescission of the agreement based on fraud and misrepresentation. S moved to dismiss for failure to state a claim, contending (1) B had disclaimed any reliance on extra-contractual representations, and (2) B had agreed the only remedy it had against $\mathrm{S}$ for misrepresentation was limited to a claim in arbitration that was capped to the extent of the \$20 million indemnity fund. B argued the language of the agreement did not limit its remedial options, and that in any event, public policy should override any attempt to limit liability for misrepresentation.

Vice Chancellor Strine concluded: (i) misrepresentations lying outside the contract are non-actionable (because of the negotiated disclaimer of reliance); (ii) the contract language contemplated the exclusive and capped "indemnity pool" as covering liability for fraud as well as contract misrepresentation; and (iii) a well-pled (i.e. with particularity) claim sounding in fraud based on contract representations known to be false and intentionally made still lies.

III. THE CRITIQUE
A. The Doctrinal Critique

${ }^{27} I d$., at 1040 . 


\section{The Source of the Problem}

I begin with a doctrinal critique. The opinion went awry, I believe, because the anti-reliance provision, and Vice-Chancellor Strine's powerful reaction to it, blinded him to the fundamental nature of the alleged wrong. To understand this, we need to unpack just what happened here.

First, Vice Chancellor Strine came to the conclusion, purely as a matter of contract interpretation, that the parties actually agreed to insulate $\mathrm{S}$ from the legal consequence of outright lying, because of the wording of the indemnity clause. S agreed to be liable for "an inaccuracy, misrepresentation, breach of, default in, or failure to perform, any of the representations, warranties or covenants" both with respect to the agreement and the sale contemplated thereby. ${ }^{28} \mathrm{~B}$ contended that the word “misrepresentation" as used in an acquisition agreement means innocent misrepresentations (as might arise if warranties and covenants turn out to be inaccurate) that appear in the agreement itself. Indeed, that is the point of the other disclaimer of extra-contractual representations: B was not to be permitted to substitute an extracontractual representation for one found in the agreement. Nevertheless, Vice-Chancellor Strine concluded that the term "misrepresentation" must have meant both misrepresentation within the agreement as well as those related to the sale but which did not constitute contractual representations. Moreover, he concluded that the ordinary meaning of "misrepresentation" included both innocent and deliberate misrepresentations. ${ }^{29}$ Combined with the contractual limitation on damages, he inferred

\footnotetext{
${ }^{28}$ Id., at 1053 nn. 40-41.

${ }^{29}$ I have real doubts, both empirically and as a theoretical matter, whether this was the correct conclusion. If, as a matter of interpretation, we consider the most likely hypothetical bargain, it seems to me highly unlikely that the parties intended to give a free pass for promissory fraud. Had the judge interpreted
} 
that the parties intended to give S a free pass on outright lying - promissory fraud - to the extent the financial impact of the lies exceeded \$20 million. Second, because it seemed there was something amiss in this result, Vice-Chancellor Strine resorted to public policy to hold that the fraud remedy (and rescission) would be available, notwithstanding the apparent disclaimer.

It is absolutely clear that Vice-Chancellor Strine had no sympathy for the apparent opportunism implicit in B's resort to the fraud remedy. "The teaching of this court ... is that a party cannot promise, in a clear integration clause of a negotiated agreement, that it will not rely on promises and representations outside of the agreement and then shirk its own bargain in favor of a 'but we did rely on those other representations' fraudulent inducement claim. $" 30$ Indeed, the judge castigates B as a liar:

To fail to enforce non-reliance clauses is not to promote a public policy against lying. Rather, it is to excuse a lie made by one contracting party in writing -- the lie that it was relying only on contractual representations and that no other representations had been made -- to enable it to prove that another party lied orally or in a writing outside the contract's four corners. For the plaintiff in such a situation to prove its fraudulent inducement claim, it proves itself not only a liar, but a liar in the most inexcusable of commercial circumstances: in a freely negotiated written contract. Put colloquially, this is necessarily a "Double Liar" scenario. To allow the buyer to prevail on its claim is to sanction its own fraudulent conduct. ${ }^{31}$

The doctrinal irony is here is that the case is not really about conflicting representations, some inside the contract and some not. Nor, as is typically the case in disputes of this kind, is it about the clear agreement of the B not to rely on puffing or

\footnotetext{
"misrepresentation" as advocated by B, the motion to dismiss would have been resolved there without resort to public policy. I will return to this interpretive issue later.

${ }^{30} I d$., at 1057.

${ }^{31} I d$. at 1058.
} 
even false statements made in the context of the complex process that is the investigation and negotiation of a business acquisition. If we consider a representation to be like a promise, then like Ayres and Klass or Vice-Chancellor Strine, we will focus on the representing party's intention to carry through on the representation or promise. And the natural focus of the disclaimer will be on the negation of an affirmative: the buyer did not rely on the representation or promise in going forward with the deal.

But that is not what happened here. The opinion goes astray with the focus on representations, as opposed to the other two ways fraud can arise: omissions and halftruths. If we merely focus on representations, the distinction between intra-contractual representations and extra-contract representations is simple because the counter-promise from the buyer is that he/she did not rely. ${ }^{32}$ But how do you disclaim an omission? Omission liability arises when there is a duty to disclose and one fails to do so. So the contract would have to disclaim the duty of disclosure. The language would read something like: "our understanding is this sale is 'as-is where is, with all faults,"” or "if I said something that was a lie, you have no remedy." In short, that is the doctrine of caveat emptor. But we do not really find that level of disclaimer in an acquisition agreement. (I have tried to write a provision that disclaims omission liability, and it is almost impossible to write, short of saying "I have the right to lie to you, and you cannot do anything about it.") We do allow due diligence, there is an expectation that you will not withhold data, and it seems to me that the fraud remedy for extra-contractual omissions is the only backstop to deal with that.

\footnotetext{
${ }^{32} I d$, at 1057 .
} 
So that brings us to the half-truth liability Vice-Chancellor Strine never addresses. Half-truth liability is based on the duty to disclose the whole truth if you make a halftruth representation..$^{33}$ It is a hybrid of affirmative misrepresentation and omission. ${ }^{34}$

Donald Langevoort asked "Why do we have law barring affirmative misrepresentation in the first place? Why don't we say that reasonable people should always do their own "due diligence" investigation rather than rely on information provided by someone with an obviously conflicting?" ${ }^{35}$ His answer is the one we would expect: we reduce transaction costs by having the knowledgeable party to disclose rather than have the uninformed party investigate. ${ }^{36}$ Langevoort observed, crucially, (a) that the same economic logic applies to half-truths, ${ }^{37}$ and (b) that it is a continuum from misrepresentation to half-truth to non-disclosure. ${ }^{38}$

Almost all nondisclosure cases arise in bargaining settings where there is indeed much said between the parties. Under these circumstances, what the court is being asked to do is determine what inferences the buyer can fairly draw from the seller's statements and omissions. Here the buyer's inferences may be more extensive - there is more interpretive work going on - but the difference is only in degree. ${ }^{39}$

Even though there are circumstances in which we may believe the informed party retains a privilege not to disclose, "the [party's] willingness to speak on the subject assuages our concern about forcing disclosure of private information, causing us to move the line

\footnotetext{
${ }^{33}$ RESTATEMENT (SECOND) OF TORTS $\S \S 529,551(2)(\mathrm{b})(1977)$.

${ }^{34}$ See Junius Const. Co. v. Cohen, 257 N.Y. 393, 178 N.E. 672 (1931) (Cardozo, J.) ("We do not say that the seller was under a duty to mention the projected streets at all. That question is not here. What we say is merely this, that having undertaken or professed to mention them, he could not fairly stop halfway, listing those that were unimportant and keeping silent as to the others.") [additional cases on half-truth liability]

${ }^{35}$ Donald C. Langevoort, Half-Truths: Protecting Mistaken Inferences by Investors and Others, 52 STAN.

L. REV. 87, 94 (1999).

${ }^{36} I d$.

${ }^{37} I d$., at $94-95$.

${ }^{38} \mathrm{Id}$., at 96 .

${ }^{39} \mathrm{Id}$.
} 
toward disclosure duty even where there is some lingering ambiguity as to the extent of the implication." 40

Professor Langevoort's continuum, it seems to me, subsumes the entire distinction between intra-contractual and extra-contractual representations Vice-Chancellor Strine was trying to make. Or to put it another way, buyer's disclaimer of reliance on an affirmative representation does NOT disclaim the "omission"-style liability that ought to arise if seller tells a half-truth. What makes these facts difficult (and interesting) is an underlying sense that courts ought not to be troubled with fraud claims as between sophisticated parties (who have the ability to ask the pertinent questions), regardless of reliance or non-reliance on anything outside the contract. ${ }^{41}$

\section{A Doctrinal Alternative}

Were I to decide the case, and I would have reached the same result as ViceChancellor Strine, but on a wholly different basis. As a result, there would have been no need to get to the public policy issue, and the holding would, I contend, be a default rule for anti-reliance clause that maps far better onto the most likely hypothetical bargain of the parties. In Sections 3.2 and 7.8 of the agreement, $\mathrm{S}$ did everything that most sellers do to focus the attention of the buyer on the express representations of the agreement, and to disclaim anything that falls outside of the agreement. ${ }^{42}$ But it did not disclaim the duty to tell the whole truth if it told part of the truth. All S did was to say that its duty-creating affirmative statement were those in the contract, not those made outside the contract.

\footnotetext{
${ }^{40} I d$., at 97.

${ }^{41}$ See Grumman Allied Indus. Inc. v. Rohr Indus. Inc., 748 F.2d 729, 737 (2d Cir. 1984).

${ }^{42}$ The "as-is, where-is" clause is interesting because sellers might argue that it negates any duty of truthtelling other than as set forth expressly in the agreement. But because my doctrinal argument is that the assertion of any representations creates the possibility of half-truth liability, the only really effective "as-is, where is" clause would be one in which the contract contains not a single affirmative statement about the condition of the business. And, as we know, that almost never happens!
} 
I would have given effect to the anti-reliance provisions in a more precise way:

The disclaimer should only be effective in the instances either (a) where the extra-contractual representation conflicts with the contractual representation, or (b) where the contract is wholly on the subject matter of the extracontractual representation. A disclaimer of reliance on extra-contractual representations cannot and should not be deemed to impact the half-truth or omission liability that may well be the natural consequence of having made the contractual representation. Moreover, the burden should be on the party asserting the anti-reliance clause to show that it was intended to cover anything but liability arising wholly as a result of the falsity of extra-contractual representations.

But to justify this result, I need to turn to theory.

B. The Theoretical Critique

1. Restating the Problem

I propose to make the theoretical problem simpler by using hypothetical

provisions. In Appendix A, I have proposed a series of hypotheticals demonstrating the increasing complexity of the misrepresentations, half-truths, and omissions that the nonreliance clause would perhaps be intended or construed to cover. For purposes of the text, I will focus on three, Cases 2, 3, and 7. In each case, the contract provides: "There are no, and Buyer disclaims any reliance on, representations or warranties, except

\section{those expressly made in the contract."}

Case 2: The contract is silent on the subject of unionization of facilities. A high-ranking officer of seller states during a management presentation says that Company A does not have any unionized facilities. It turns out the company does have a unionized facility. In this case, I would give effect to the anti-reliance clause. By its silence on the subject, the contract created an implicit conflict between the external and internal representations. There were no representations about unionized facilities within the 
contract on which Buyer could rely per its own agreement, and the provision exculpates Seller.

\section{Case 3: The contract states that the company does not have any unionized}

facilities. There are no other extra-contractual representations, but the same high-ranking officer of the company knows that the workers at more than one plant have approved the formation of a union, but the union election has not yet been certified by the National Labor Relations Board, and so technically the company still does not have any unionized facilities.

Here, the outcome will depend on the interpretation of the word "unionized." Was it intended to include an approved but uncertified union as well as established unions? That is unclear. If it is absolutely clear to all concerned that "unionized facilities" does not include one in which the union has been approved but the election has not been certified by the NLRB, then there can be no fraud, because there is no untrue statement. But what is the relationship of scienter to the ambiguity of the original representation? The example demonstrates the possibility of a half-truth, even in what would have seemed at the outset to be a simple and clear affirmative representation. A laissez-faire or purely contractual approach would place the burden on the buyer to obtain the correct information by asking the correct question, or to create express liability by the prospective elimination of any possible ambiguity.

Case 7: The contract states that the company's financial statements fairly present in all material respects the financial condition of Company on the dates and for the periods presented in accordance with generally accepted accounting principles consistently applied. As in Abry, the company booked "return reserves." 
The standard for "return reserves" under GAAP is that they must be based on a reasonable estimate of expected returns. The chief financial officer issued a memorandum to all business unit controllers indicating that it was important for the purpose of the impending sale of the company that all return reserves be in accordance with GAAP, but nevertheless to err on the side of low estimates rather than high estimates. This had the effect of making the earnings look higher. Sellers deliberately did not disclose this memorandum in due diligence. Presumably the court in Abry would hold the otherwise actionable facts to be beyond the scope of the contract due to the disclaimer. I would conclude that the original representation was an assurance that seller is not playing games and telling half-truths outside the contract. Hence, the representation itself created a duty of full disclosure, whether inside or outside the contract. And I would not find an extra-contractual remedy to be troubling. If the seller failed to tell the whole truth within the contract, why should the buyer be limited to the remedy inside the contract? ${ }^{43}$

\section{An Efficiency Critique}

We begin with a efficiency analysis, not so much because I believe that is the only reason for my rule, but because the role of the law in promoting efficient business transactions was important to Vice-Chancellor Strine. The notions of predictability and

\footnotetext{
${ }^{43}$ I also propose a somewhat simpler hypothetical that I think raises the same half-truth issue as in Case 7 of the Appendix. Seller and Buyer write a contract for the sale of a car. The sale is "as-is, where-is" except that the Seller represents and warrants that the tires were replaced at 40,000 miles. The contract contains the following clause: "There are no, and Buyer disclaims any reliance on, representations and warranties, except those expressly made in the contract." Buyer discovers after purchasing the car that the tires were not replaced because of ordinary wear and tear, but because the car had been in an accident that had caused the tires to be destroyed. A reasonable inspection of the car did not reveal any other indication of an accident. Buyer would not have bought the car had it known of the accident.

Does Buyer have a claim for fraud? It is undisputed that Buyer has an affirmative right to rely on the tire representation. I will also assume for the sake of the discussion that, in the absence of the tire representation, B would have no rights vis-à-vis the accident. The questions, then, are (a) did the representation about the tires create a duty to tell the whole truth about the replacement, and (b) did the disclaimer impact any such duty?
} 
certainty (as hallmarks of economic efficiency) are mantras in the justification of contract law. They are also a theme in Delaware's effort to compete for the application of its law. ${ }^{44}$ Indeed, Vice-Chancellor Strine attempts, on one hand, to reconcile Delaware's pride in the efficiency of its commercial law, ${ }^{45}$ against its abhorrence of immunizing fraud, on the other; ${ }^{46}$ indeed, citing a single passage from Judge Posner's seminal text to support what appears to be an economic justification of the difference between intentional lying and innocent misrepresentation. ${ }^{47}$ The primary basis for justifying the contractual disclaimer of reliance on the truthfulness of assertions is that these provisions, when used, are efficient, promoting predictability and certainty.

I contend my rule of construction, which would preserve the fraud claim in all but the clearest cases of broad-based disclaimer, is in fact the most efficient result. A similar analysis of promissory fraud in Insincere Promises is instructive. As I have noted, the concerns there are somewhat different from mine. Indeed, I will contend that the choice of default rule - one that is information-forcing rather than majoritarian (at least in the first instance - ought to differ when we are talking about the difference between a descriptive use and a performative use of language. Ayres and Klass would be concerned about the circumstance where a buyer or seller says "I promise to close on September 30" with no present intention of performing on the promise. The issue in the archetypal Abrystyle deal is not whether the seller intends to close. That is a given. The question is how

\footnotetext{
${ }^{44}$ See, e.g., Chancellor William Allen, The Pride and the Hope of Delaware Corporate Law, 25 DEL. J. CORP. L. 70, 71 (2000); Chancellor William B. Chandler III, The Role of the Delaware Court of Chancery as a Specialized Business Court, Address at Moritz College of Law, The Ohio State University (Mar. 17, 2006), archived webcast available at http://moritzlaw.osu.edu/eblj/symposium.html (last visited, Apr. 29, 2006).

${ }^{45} 891$ A. 2 d at 1060 n.67.

${ }^{46} \mathrm{Id}$., at 1061 .

${ }^{47} I d$., at 1062 n. 78 (citing Richard Posner's ECONOMIC ANALYSIS OF LAW to the effect that lying is inefficient).
} 
to interpret a disclaimer of reliance in the face of a statement that $x$ is true about the business.

So it is helpful to trace through the process by which Ayres and Klass select a default rule in order to understand the Coaseian parameters at play, and to distinguish the problem of a secret intention not to perform from the problem whereby a seller says part but not all of what is true about a business. J.L. Austin's insight was to identify those speech acts that are not descriptive of an independent state of reality, that is not capable of being either true or false, but are themselves the very reality. Examples of performatives include marriage vows, promises, bequests, and namings. ${ }^{48}$ So the issue for Ayres and Klass is whether the words appearing to create a performative were so intended as such by the speaker.

But in order to determine whether the promisor intended, at the time of the promise, to perform, it is first necessary to interpret what the promisor promised. ${ }^{49}$ Ayres and Klass lay down a set of interpretive defaults and rules for contracting around them, and those rules apply almost wholesale to the disclaimer problem.

Ayres and Klass do not advocate the elimination of the parties' ability 'to choose what to say or not to say about their intentions, about the probability of their performance, and about whether they think it in the promisee's self-interest to rely."50 Their only mandatory rule is that "[e]very promise represents at least that the promisor does not have an intention not to perform."51 The question then is the appropriate default rule, around which the parties may choose to negotiate. Such a default could be based

48 J.L. AUSTIN, How to Do Things With WORDS (1955).

${ }^{49}$ AYRES \& KLASS, supra note 1 , at 86.

${ }^{50} \mathrm{Id}$., at 89 .

${ }^{51} I d$., at 90 . 
primarily on "what the majority of contracting parties would choose," on one hand, or "information-forcing effects," on the other (although it is entirely possible that the majoritarian default has information-forcing effects, or vice versa). ${ }^{52}$

Ayres and Klass posit that a promise could have default interpretations across a continuum of meaning about the probability of performance (from definite to positive to opaque), as well as the promisor's assurance to the promisee that the promisee should feel comfortable in relying on the promise (from fully warranting to semi-warranting to non-warranting). Their conclusion is that performatives that look like promises should be subject to two default representations, which they call "positive," which relates to the promisor's expectation that it will perform, and "semi-warranting." In other words, "A's statement 'I promise to $x$ ' should be that A says both that she intends to $x$ and that she doesn't believe that the probability of her xing is so low that it is not in the promisee's rational self-interest to rely [semi-warranting]. In addition, the default meaning of A's saying that she intends to $x$ is that there is at least a 50 percent chance that she will $x$ [positive]." 53

We should note that Ayres and Klass have not opted for a default rule that would force the most information. The promise performative can be presumed to be richer or poorer in information. We can presume that promises "tell the promisee that the probability of performance is at least some value (definite-probability), that the probability of performance is so great that the promisee can safely rely on it (warranting), or that the probability of performance is secured by the promisor's intention to

\footnotetext{
${ }^{52} I d$.

${ }^{53} I d$., at 99 .
} 
perform." ${ }^{, 54}$ Whether a promise is construed to include a warranty about the promisee's level of reliance, it requires the promisor to gather information about the promisee. Ayres and Klass conclude that while "if our only concern were to maximize information disclosure, the best interpretive default would be that a promise simpliciter is both positive and fully-warranting." 55 What this means is that if the promisor thought the likelihood of performance was low enough that the promisee ought not rely on it, the promisor would be obliged to say so, or be liable for promissory fraud. Because this would require the promisor to gather information about the promisee's need or desire to rely, Ayres and Klass contend that such a default "would not reflect what most promisors would choose to say with their promises."

It is important, however, to distinguish between the proposed default rule as it relates to the creation of a performative versus the purely descriptive aspects of the representation. Ayres and Klass think the information costs will be too high, and therefore sub-optimal for the encouragement of value-creating promises, if a promisor is presumed to have made full warranties about the promisee's ability to rely. Yet the positive default rule on the promisor's own intent is information-forcing - "absent contrary circumstances, a promise represents that the promisor intends to perform." ${ }^{, 57}$

A performative is, however, necessarily an affirmative representation. Let us now consider the Abry issue, in which we seek to set a default rule for the scope of seller's representations in the face of the buyer's disclaimer of any reliance on extra-contractual matters. The same efficiency-enhancing information-forcing default rule that requires the

\footnotetext{
${ }^{54} I d$., at 90 .

${ }^{55} I d$., at 100 .

${ }^{56} \mathrm{Id}$.

${ }^{57} I d$., at 206.
} 
promisor to disclose if she does not intend to perform supports liability, as in Case 3, where the promisor deceives intentionally by making representations that are only partially true.

Information-forcing defaults tend to penalize one or both parties, giving them an incentive to reveal information in order to opt out of the default. The desirability of an information-forcing default falls under the heading of informational effects and is governed by the general principle that interpretive rules should give parties an incentive to disclose the optimal amount of information. ${ }^{58}$

For purposes of stating a default rule, we ought to be able to say, as a matter of common sense, that it is cheaper for the warrantor than the warrantee to determine whether an affirmative statement has created a half-truth. It is entirely possible this may not be the case, but then it is incumbent on the speaker to take some action to provide a warranty other than the one that creates the half-truth; i.e. to contract around the default rule. To call the buyer's statement that it is not relying on extra-contractual representations such an avoidance of the default rule is to forsake the information-forcing nature of the acquisition agreement; the exercise becomes a word game.

Moreover, placing the burden of the default rule on the discloser makes sense intuitively, if we consider the motivations in the sale of a business. This is the classic prospect theory advanced by Kahneman and Tversky. ${ }^{59}$ At the closing of a deal, by and

\footnotetext{
${ }^{58} I d$., at 99.

${ }^{59}$ Daniel Kahneman \& Amos Tversky, Prospect Theory: An Analysis of Decision Under Risk, 47 ECONOMETRICA 263 (1979); see also Christine Jolls, Cass R. Sunstein, \& Richard Thaler, A Behavioral Approach to Law and Economics, 50 STAN L. REV. 1471, 1478 (1998).

One of the central features of Kahneman and Tversky's prospect theory is that people evaluate outcomes based on the change they represent from an initial reference point, rather than based on the nature of the outcome itself; also, losses from the initial reference point are weighted much more heavily than gains. This aspect of prospect theory (like its other features) is based on evidence about actual choice behavior. The evaluation of outcomes in terms of gains and losses from an initial
} 
large, the seller receives present cash against the possibility that the buyer may make a claim at some time in the future. My casual empiricism is that sellers view a lost sale as a loss, and weigh that loss far more heavily than the future prospect of liability under an indemnity clause. Hence, the natural inclination is to minimize problems, not to disclose.

\section{A Linguistic and Social Critique}

There is something more than economic incentive at play in setting the default rule for the fine line between innocent and deliberate misrepresentation and the intra- and extra-contractual instances of truth telling. Ayres and Klass recall the relatively amoral Holmesian interpretation of a contract: the promise is either to perform to pay damages for non-performance ${ }^{60}$ What comes through, notwithstanding the law's primary concern in commercial matters for consequences, is distaste for the efficient breach, at least when it was preceded by an intention never to perform. By all accounts, legal, economic, and moral, we start with a presumption of truth-telling. Vice-Chancellor Strine makes it clear that the presumption is that even extra-contractual statements carry with them a presumption of truth-telling upon which fraud could be based, if the parties "do not clearly state that the parties disclaim reliance upon extra-contractual statements. ... If parties fail to include unambiguous anti-reliance language, they will not be able to escape responsibility for their own fraudulent representations made outside of the agreement's

reference point, coupled with the special aversion to losses, means that it matters a great deal whether something is presented as a gain or a loss relative to the status quo; a perceived threat of a loss relative to the status quo weighs more heavily than a perceived threat of foregoing a

Id. at $1535-36$. gain.

${ }^{60}$ AYRES \& KLASS, supra note 1, at 4-5. See Oliver Wendell Holmes, The Path of the Law, 10 HARV. L. REV. 457 (1897), reprinted in 110 HARV. L. REV. 991, 996 (1997) ("the duty to keep a contract at common law means a prediction that you must pay damages if you do not keep it, - and nothing else). 
four corners. ${ }^{.61}$ But if it is a moral concern, it is one grounded not in a duty of truthtelling, but a concern for commercial consequences if lying is permitted. The court's rejection of a disclaimer of promissory fraud is primarily based on efficiency grounds: "there is little support for the notion that it is efficient to exculpate parties when they lie about the material facts on which a contract is based." ${ }^{, 62}$ Indeed, the supporting footnote for the preceding sentence is to Judge Posner's seminal text, in which he simply declares flatly "[t]he lie is different. The liar makes a positive investment in manufacturing and disseminating misinformation. This investment is completely wasted from a social standpoint. ${ }^{, 63}$

And yet, it is not wholly a consequential matter. As Vice-Chancellor Strine states:

I use the plain word "lie" intentionally because there is a moral difference between a lie and an unintentional misrepresentation of fact. This moral difference also explains many of the cases in the fraus omnia corrumpit strain, which arose when the concept of fraud was more typically construed as involving lying, and thus it is understandable that courts would find it distasteful to enforce contracts excusing liars for responsibility for the harm their lies caused. ${ }^{64}$

I believe there is a reason for this confusion. I am not sure, were Judge Posner to consider it more deeply, that he would conclude some lies, particularly of the "white lie" variety, might well be efficient. ${ }^{65}$

\footnotetext{
${ }^{61} 891$ A.2d at 1058-59.

${ }^{62} I d$., at 1062 .

${ }^{63}$ RichARD A. POSNER, ECONOMIC ANALYSIS OF LAW $\S 4.6$ ( $5^{\text {th }}$ ed. 1998).

${ }^{64} 891$ A.2d at 1062.

${ }^{65}$ Indeed, one of the objections to Kant's own categorical views on lying to save a friend is that the result is, nevertheless, offensive to our moral intuition. At the risk of political incorrectness, there is also the Talmudic injunction that it is not morally wrong to tell a bride the white lie that she is beautiful even when she is not. See Sir Jonathan Sacks, "The White Lie," from Covenant and Conversation (Dec. 24, 2004), http://www.chiefrabbi.org/tt-index.html (last visited, Dec. 19, 2006). Presumably, from the standpoint of
} 
The issue before is simply how broadly to interpret a disclaimer of truth-telling when it appears in a contract. Like Vice-Chancellor Strine, I have no particular compunction against a buyer freely agreeing that it imposes no duties whatsoever upon the seller to say anything at all, truthful or not about the business. It is certainly possible to write a provision in an agreement that says: "Buyer is simply buying the business. It acknowledges the possibility that nothing the Seller has said in the contract is wholly true, particularly in view of facts or circumstances Seller may have intentionally or unintentionally failed to disclose, and Buyer hereby absolves Seller of any duty to clarify what in hindsight may be deemed to have been a half-truth." So I do not really think that the question turns on what the law of Delaware might endorse as a matter of moral philosophy - whether utilitarian efficiency, on one hand, or deontological revulsion against the telling of lies, on the other. Either might well be the basis for law, but neither really captures the complex context of a heavily negotiated business acquisition agreement.

The counter-thesis is that it is a linguistic jungle out there, full of outright lies, non-disclosures, and half-truths, and the only protection is what one's lawyer is able to capture in the four corners of the documents. That counter-thesis is consistent with the re-emergence in modern contract theory of formalism, ${ }^{66}$ particularly in complex transactions, on the presumption that sophisticated business people would prefer that

the parents of the bride, this particular investment in deception was not completely wasteful from a social perspective.

${ }^{66}$ Mark L. Movsesian, Formalism in American Contract Law: Classical and Contemporary, forthcoming, 11 IUS GENTIUM (2006), available at http://papers.ssrn.com/sol3/papers.cfm?abstract_id=894281; Jeffrey M. Lipshaw, Contract Formalism, Scientism, and the M-Word: A Comment on Professor Movsesian's Under-Theorization Thesis, forthcoming, 35 HofSTRA L. REV., No. 1 (Fall, 2006) (available at http://ssrn.com/abstract=909299). 
approach. ${ }^{67}$ I suggest instead that the basis for the presumption of truth-telling (and the concomitant narrow construction of disclaimers of truth-telling) is based in more fundamental properties of speech acts, and in our everyday expectations of each other.

In the remainder of this article, I want to take a dive into language and social theory as an alternative basis for having courts presume that the parties (a) did not adopt the doctrine of caveat emptor, and (b) did undertake the agreement with some consciousness of the law of fraud. Accordingly, any contract language purporting to allow, expressly or implicitly, the right to lie should be construed narrowly. A model, or inspiration, for this project may be Dennis Patterson's introductory comments to his attempt to article a general theory of good faith under Article 9 of the Uniform Commercial Code. ${ }^{68}$ The problem is interesting because it is, as Professor Patterson observed of the U.C.C., a concrete problem that nevertheless might be illuminated by alternative theoretical approaches. ${ }^{69}$

a. Presumptions Based on the Use of Language and the Warranties of Speech Acts

(1) The Illusion of Power over Interpretation

When we rely on the blunt instrument of language to describe the fine lines of which statements were relied upon and which were not, absolute predictability and certainty collapses, and rightly so. Insights from the philosophy of language raise

\footnotetext{
${ }^{67}$ Cf. Alan Schwartz \& Robert Scott, Contract Theory and the Limits of Contract Law, 113 YALE L. J. 541 (2003).

${ }^{68}$ Dennis M. Patterson, Wittgenstein and the Code: A Theory of Good Faith Performance and Enforcement Under Article Nine, 137 U. PA. L. REV. 335, 335-341. Professor Patterson quotes a call that seems to me even more apropos some twenty years after it was made. "We need more legal studies that aren't narrowly internalist renditions of doctrine, but that don't try to reduce doctrine to an epiphenomenal reflex of economics or anything else. We need more legal studies that aren't obsessed with the drama of appellate review. Instead we need richly theoretical ways to explore the interaction of law and other institutions." Don Herzog, As Many as Six Impossible Things Before Breakfast, 75 CALIF. L. REV. 609, 630 (1987). I do not presume any success, but it is an aspiration for this piece.

${ }^{69}$ Id., at 338-41.
} 
questions about the parties' ability fully to capture the agreement in words to a scientific certainty. The first problem is in the interpretation of the word "misrepresentation." P.S. Atiyah, citing Wittgenstein's “family resemblance” argument, commented on just this situation:

Too often, the problems which have beset the contract arise precisely because the parties did not foresee the events which have occurred, and they did not, therefore, have any relevant intentions at all. It is true, of course, that a person may use language intended to cover (or exclude) a general class of things without necessarily adverting to each known example: "Someone says to me: 'shew the children a game.' I teach them gaming with a dice, and the other says, 'I didn't mean that sort of game.'"70

Hence, the issue is not the assiduousness or preparedness or foresight of the lawyers. It is the problem that language and the law are blunt instruments that are often incapable of drawing the fine line of the implicit understanding.

The exercise is foremost one of interpretation. "We interpret an utterance when we choose between different ways of understanding it. Legal interpretation is the activity of deciding which of several ways of understanding a given provision is the correct or preferable way of understanding."71 The target of our interpretive exercise is the utterance in the contract concerning the agreement to rely only on those representations and warranties made in the agreement. We need to parse the language of the anti-reliance clause as linguistic sign. To understand what the parties mean when they recite that the buyer is relying only on the representations and warranties contained in the agreement, we must assess it "against the background of public, intersubjective practices." 72 We are

\footnotetext{
${ }^{70}$ P.S. ATIYAH, Promises, MORALS, AND LAW (1981), at 89.

${ }^{71}$ Dennis M. Patterson, Interpretation in Law, forthcoming, SAN DIEGO L. REV., available at http:ssrn.com/abstract=702921 (2006), at 3 n.3.

72 Patterson, Wittgenstein, supra note , at 356.
} 
projecting several concepts - reliance, representations, warranty - onto the reality of a relationship between the seller and the buyer. The words are part of the "language game;" as Wittgenstein describes, "the whole, consisting of language and the actions into which it is woven." ${ }^{, 73}$ Patterson quotes Stanley Cavell's explanation of the grammar of a chair. We imagine the concept of a chair. It is not merely something on which we sit. It is not even something on which we sit that serves all the functions of a chair (a rock pushed up against a wall may serve as a chair but it is not a chair). "What can serve as a chair is not a chair, and nothing would (be said to) serve as a chair if there were no (were nothing we called) (orthodox) chairs., 74

To sweep representations into half-truths or omissions, and to ignore their differences, is to ignore the grammar of the "reliance." An omission or half-truth is no more a representation that something that serves as a chair is a chair. It is somehow related but it is not the same. We cannot rely on an omission, and to suggest that by disclaiming reliance on a representation we have somehow impacted omissions is to ignore, or at least gloss over an important distinction.

This is the trap to which Vice-Chancellor Strine succumbed in his interpretation of the indemnity clause. If the word "misrepresentation" in the indemnity clause did not include an intentional misrepresentation, but only the innocent circumstance under which the facts did not match up to the contractual representation, there would have been no issue whether Delaware would recognize the right to lie. The problem arose because Vice-Chancellor Strine took the contractual provision to anticipate outright lying, and, a fortiori, more subtle forms of deception, like half-truths and palliatives. Here, there is a

\footnotetext{
${ }^{73}$ Ludwig Wittgenstein, Philosophical InVestigations (G. Anscombe trans. 3d ed. 1968), §7, at 5.

${ }^{74}$ S. CAVell, The Claim of REASOn 71 (1979), quoted in Patterson, supra note , at 362.
} 
question whether we are even talking the same language; the court turns to the legal lexicon to define misrepresentation, citing Black's Law Dictionary, and not to what the words signify as linguistic signs in the deal context. "Someone says to me: 'Shew the buyer an indemnity clause protecting him against misrepresentation.' I include a contractual indemnity against fraud, and the other says 'I didn't mean that kind of misrepresentation."

The benefit of contractual representations is that they are a form of strict liability; all we need determine is if they are untrue (or perhaps materially untrue). It is something altogether different to indemnify not only against the misrepresentation being untrue, but also against the state of mind of the speaker at the time the representation was made. The anti-reliance disclaimer makes perfect sense when applied against strict liability assertions of the state of the business. But it becomes nonsensical when the purpose of the assertion was the deception by half-truth, and the essence of the wrong is in what was not said, and could never have been the subject of reliance.

It is a particular conceit of lawyers (and many lawyer-scholars), however, that they can obtain control over the world with a unique ability to map language on reality. Yet, I would contend this is not the case even among lawyers. That there may be a gap between language and reality is the upshot of thinking in the philosophy of language in recent years. Benjamin Zipursky has observed:

$[\mathrm{W}] \mathrm{e}$ now realize that the idea that language represents reality is a myth. In fact, the languages of various communities are simply tools we use to get around, to interact, to impose norms on one another, and to carve the world up as we wish at any point in time. Any particular community at any particular time is roughly limited by its language and its conceptual scheme to seeing the world a certain way, but the connection between language and world is ultimately ineffable. Moreover, even with respect

${ }^{75} 891$ A. 2 d at 1053. 
to individual speakers, the task of interpretation is daunting, and fundamentally indeterminate. ${ }^{76}$

The most articulate response to my thesis - that the contractual disclaimer has to be construed narrowly - is that contract negotiations among sophisticated parties are a stylized, ritualized business, and the ordinary use of language defers to the particular language of lawyers (and I suppose business people) in that particular setting. Indeed, one responder said that the reason for the writing was to speak to a judge some day if necessary; hence, even more support for the notions that the only words with meaning were those expressly set forth, at least in the face of the disclaimer.

The thesis is controversial because it tends to undercut the lawyer's self-image of value creation, something on which it is difficult to have a balanced perspective if one always been a lawyer, looking at the world through lawyer's eyes. In particular, one response to the thesis is that making the language clear and precise is what we do as lawyers, and why do we bother if that's all for naught? To the contrary, say my colleagues, we operate in a special community of language technicians, in which the relative cost-avoiding positions of the receiver of the statement and the maker of the statement are up for grabs. $^{77}$

Yet even these language specialists react in ordinary ways when they are the victims of the close parsing of language. Let us consider a thought experiment in which every relevant participant is a lawyer and, hence, an equally proficient parser of language. A lawyer related the story of a witness at an evidentiary hearing on whether to

\footnotetext{
${ }^{76}$ Benjamin C. Zipursky, Legal Coherentism, 50 SMU L. Rev. 1679, 1680 (1997).

${ }^{77}$ Peter Tiersma, Some Myths About Legal Language, available at http://ssrn.com/abstract=845928.
} 
lift a temporary restraining order that had been issued in a trademark infringement case. ${ }^{78}$ The issue was laches - whether the plaintiff had known about the infringement but nevertheless sat on its rights. The TRO had been issued in part on the basis of an affidavit of one of plaintiff's officers that he first became aware of the issue in August. The cross-examining lawyer learned that the officer had really heard about it back in February or April but somehow his affidavit (drafted by his lawyer) ended up with the far more favorable, from a laches perspective, unequivocally false statement that he first heard about the problem much later.

Assume, for my purposes, that the witness (call him Smith) told his lawyer (call her Ms. Jones) he heard about the infringement in April, then forgot about it, then recalled again in August. So his affidavit says "I became aware in August." This statement is literally true, but it is a half-truth, because what is left out is that Smith also became aware in April. Assuming plaintiff is chargeable, for laches purposes, with Smith's earlier becoming aware, it is a significant half-truth.

Ms. Jones has deliberately fudged the truth. In the adversarial setting, is it fair game to fudge, and then incumbent on Ms. Jones' opponent (call her Ms. Johnson) to ferret out the full truth? Presumably, Ms. Jones and Ms. Johnson are equally capable of discerning impreciseness in language that gives rise to the ambiguity that in turn gives rise to the half-truth (i.e. does "became aware" imply "first became aware")? And assuming Ms. Johnson misses the trick, the judge is also a lawyer, and is also, presumably, as capable as either lawyer of discerning that kind of trick.

\footnotetext{
${ }^{78}$ For the original story, see William J. Dyer, A Long War Story About a Beldar Cross-Examination, and a Technical Bleg About Meta-Data, available at http://beldar.blogs.com/beldarblog/ 2006/11/technical_bleg_html.
} 
So why is everybody so angry (particularly the judge) when it turns out that Ms. Jones has slicked both Ms. Johnson and him? My thesis is that even sophisticated lawyers presume the truth of the words in their communicative action, accordingly to a community standard that is far less precise than lawyers (or economists) would generally like to think. We have an intuitive reaction, even as sophisticated lawyers, that we have been wronged in this instance. If we credit my general thesis about default interpretations as applied to half-truths, we can muster a coherent explanation of the source of the dilemma. But if, in my thought experiment, I make all the lawyers and judges fully rational actors in their use of language, there is no accounting for the sense that something has gone terribly amiss. ${ }^{79}$

\section{(2) The Implicit Warranties of Speech}

But the issue is not merely interpretation. There are implicit and pre-conscious warranties in language. That is, we begin with the proposition that we say or seem to be saying ought to be taken at face value. As noted earlier, the contractual representations and warranties are merely descriptive and not performative. ${ }^{80}$ It seems to me those descriptive utterances have linguistic truth warranties to them that precede any legal warranties. To put it another way, if the thesis is that every statement in a negotiation is a potential lie, and can only be given truth content by virtue of the contract, it is only the contract and not our ordinary language that is communicate. In short, we have reversed the intuitive use of language.

\footnotetext{
${ }^{79}$ For more anecdotal evidence of the ordinary human reaction judges have to the deceptive use of language, see Alan Childress, "On Further Review: Need More Serious Reaction to Too-Clever Lawyering, ” LEGAL PROFESSION BLOG, available at http://lawprofessors.typepad.com/ egal_profession/2006/12/needed_seruous_.html.

${ }^{80}$ J.L. Austin, How TO Do THINGS WITH WORDS (1962).
} 
We can unpack this by reference to Habermas's distinction between discourse and communicative action. ${ }^{81}$ Habermas focuses on language as the means (and the sole means) by which we have inter-subjective communicative action. Taking a Kantian perspective, he intuits an access to universal norms that go beyond mere empiricism. To Habermas, it is simply counterintuitive to believe the positive science of the physical world is all there is. Nevertheless, he is unwilling to posit a completely subjective access to truth, and this insight is derived from the development in philosophy he refers to as the "linguistic turn." Following on Wittgenstein, language is how we intermediate between our selves and our world. Wittgenstein demonstrated (akin to Kant's deduction that there is an objective world as to which each subject is observer) that there are no private languages. That is, if our minds conceive of ideas in a wholly private language, it is though those ideas did not exist because they cannot be communicated to anyone. Indeed, language is itself a social structure, and we are assuming too much about our own raw individuality if we assume we are so alone as to have developed the very medium by which we express our ideas.

So what is our agreement? When we begin to discuss our individual goals and the possibility of the attainment of value through mutual understanding and a bargain, we do so through language, the only means by which such discussion is possible. "Let's agree that the price escalates by increases in the cost of living," says one of us. When we have a handshake agreement or a preliminary understanding like this, it is still an exercise in inter-subjective understanding by the intermediation of language. But our lawyers show us the ways in which that communication might break down. "Did you mean to measure

\footnotetext{
${ }^{81}$ JÜrgen Habermas, ON THE Pragmatics OF Social Interaction, trans. Barbara Fultner (2001), 89-93.
} 
that increase by the consumer price index? Or by the wholesale price index? For which goods and services? And in which geographic areas?"

This provides the lawyer's analog to Habermas' discourse ethics. When a speaker asserts a proposition, and the listener purports to understand it, there are implicitly four "background" claims being made with respect to the proposition. These are not, in the ordinary course, at the top of mind (they only become so when there is what Habermas calls a breakdown in communicative action), but they are a priori aspects of the way we process each other's speech (akin to Kant's categories of the understanding in ordering the data of the outside world):

- The proposition is intelligible - the speaker and the listener each understand something from the proposition - it is syntactically correct and follows the accepted "internal relation between symbolic expressions and the relevant system of rules, according to which we can produce these expressions." "An utterance is intelligible if it is grammatically and pragmatically well formed, so that everyone who has mastered the appropriate rule systems is able to generate the same utterance." An example is Bertrand Russell's famous example: The present King of France is Bald." The sentence is nonsensical but nevertheless we understand it syntactically. $^{82}$

- As to statements making truth claims, each party recognizes the truth of the proposition. "Truth is a relation between sentences and the reality about which we make statements."

\footnotetext{
${ }^{82}$ Bertrand Russell, On Denoting, 14 Mind 479 (1905). The problem, under Russell's treatment, is that we recognize the phrase "the present King of France" as one that denotes, even though there is no real king to which the phrase refers.
} 
- As to statements making normative claims, each party acknowledges the normative rightness of the norm that the statement may be fulfilling. This is distinct from truth: the implicit claim is "that it is right to recognize a prevailing norm and that this norm 'ought' to have validity."

- Neither party casts doubt on the sincerity of the other. "A speaker is sincere if she deceives neither herself nor others. Just as "truth" refers to the sense in which I can put forth a proposition, 'sincerity' refers to the sense in which I disclose or manifest in front of others a subjective experience to which I have privileged access." 83

Most of the time we communicate without any consciousness of the underlying validity claims of our speech. But it is certainly possible to contest either the truth or the normative rightness of an assertion. Truth involves grounding an assertion in experience (or at least not being subject to a showing of contradictory experience). Normative rightness, on the other hand, makes no claim against experience, but claims of normative rightness can be considered universal only if all involved in rational discussion would agree to their rightness "under ideal conditions." 84 Normative rightness goes beyond mere empiricism - it "idealizes" a universal norm.

\footnotetext{
${ }^{83}$ Habermas, On the Pragmatics of Social Interaction, supra note , at 89-93.

${ }^{84}$ HABERMAS, TRUTH \& JUSTIFICATION, supra note , at 36-40. Ideal conditions of discourse are: (1) public debate and complete inclusion of all affected, (2) equal distribution of the right to communicate, (3) non-violent context in which only the force of the better argument prevails, and (4) sincerity on the part of all who express themselves. Id., at 37. In his earlier work, Habermas maintained that truth assertions had to be "redeemed" through argumentation in "ideal conditions." As I understand his position as of the publication of TRUTH AND JUSTIFICATION in 2003, he appears to have come to the conclusion that requiring "ideal conditions" is not necessary to the acceptance of truth claims, because it would preclude the possibility of even a universally accepted claim being disproved later. Nevertheless, he continues to acknowledge the regulative aspect of reason in the assertion of scientific claims, and so discourse and argumentation are necessary.
} 
Moreover, to Habermas, the linguistic turn in philosophy makes pragmatic what had been Kant's attempt to distinguish the "noumenal" or "transcendental" versus the "phenomenal" or "empirical:"

The idea of the redeemability of criticizable validity claims requires idealizations that, as adopted by the communicating actors themselves, are thereby brought down from transcendental heaven to the earth of the lifeworld. The theory of communicative action detranscendentalizes the noumenal realm only to have the idealizing force of context-transcending anticipations settle in the unavoidable pragmatic presuppositions of speech acts, and hence in the heart of ordinary, everyday communicative practices. ${ }^{85}$

In other words, when you make a statement about what ought to be, even in the most mundane circumstances, you are claiming one kind of validity or another in what you say. The test of validity of normative statements is not correspondence with facts in the world, but with reasons that justify the universality of the claim, even if you have not stated them. ${ }^{86}$ The process of argumentation and attainment of rational consensus around either truth or normative rightness - the redemption of the validity claim - is what Habermas calls discourse. $^{87}$

Ibid., 38.

Despite this revision, the concept of rational discourse retains its status as a privileged form of communication that forces those in it to continue decentering their cognitive perspective. The normatively exacting and unavoidable communicative presumptions of the practice of argumentation now as then imply that impartial judgment formation is structurally necessary. Argumentation remains the only available medium of ascertaining truth since truth claims that have been problematized cannot be tested in any other way. There is no unmediated, discursively unfiltered access to the truth conditions of empirical beliefs. After all, only the truth of unsettled beliefs is open to question - beliefs that have been roused from the unquestioning mode of functioning practical certainties.

${ }^{85}$ JÜRGEN HABERMAS, BEYOND FACTS AND NORMS, trans., William Rehg (1998), at 18-19.

${ }^{86} I d$., at 19.

${ }^{87}$ HABERMAS, TRUTH AND JUSTIFICATION, supra note , at 36-42. There is a natural segue from discourse ethics to the process of adjudication, but in the end, Habermas concludes it is problematic to equate them. 
The kind of rational discourse in which a lawyer might parse language to the extent that one expressly, rather than implicitly, warrants the truth, ought not to be the presumed default state. We communicate as normal human beings; lawyers engage in discourse, whether it is in the ex ante attempt to make communication precise, or in the ex post exercise of figuring out what a communication meant. The lawyer's exercise is to predict the inevitable breakdowns in the "unavoidable pragmatic presuppositions of speech acts."

The half-truth is the most pernicious kind of lie, under this reasoning, because it violates not only the warranty of truth, but the warranty of sincerity. The subjective experience to which the speaker has access is the whole truth, yet it remains unspoken. Discourse is not even possible, because we do not have a shared speech act as to which we may jointly perceive the possibilities in which the proposition fails to mirror reality. Even in the communicative action we must undertake to explain its breakdown and cure it by discourse, we must presume sincerity. As Ayres and Klass observed about the complexity of a speech act: "In most cases, a promisor's representation that she intends

Habermas proposes an alternative theory of legal discourse that responds to the positivist-naturalist debates over certainty and legitimacy in law. This is a theory of argumentation, much like Patterson's: there are many norms that may be applied in a particular case, and the argument, more often than not, turns on the selection or interpretation of the norm:

[L] egal hermeneutics has the merit of having revived the Aristotelian insight that no rule is able to regulate its own application. If we consider a case to be a state of affairs falling under a rule, then such a case is constituted only by being described in terms of the norm applied to it. At the same time, the norm acquires a more concrete meaning precisely in virtue of its application to a corresponding state of affairs, which is thereby transformed into a case. A norm always "takes in" a complex lifeworld situation only in a selective manner, in view of the criteria of relevance prescribed by the norm itself. At the same time, the single case constituted by the norm never exhausts the vague semantic contents of a generalized norm but rather selectively instantiates them.

Habermas, Beyond Facts and Norms, supra note , at 199. 
to perform does not require a separate utterance - 'This casserole is sine cera' - but is understood to be part of the meaning of the very act of promising." ${ }^{, 88}$ I contend it would be a linguistically impossible act of schizophrenia to operate, even in the most sophisticated, arms'-length setting, on the presumption that every speech act except the one embodied in the language of the contract is potentially insincere.

Accordingly, the proper presumption for disclaimers of sincerity is that they only apply to the extent they are patently and expressly clear, and then only in the narrowest possible way.

b. Disclaimers of Truth-Telling as Social Phenomenon (1) The Lawyer's Constitutive View of Contracts

The position proffered by some scholars - that buyers should expect all representations other than those warranted to be lies, and if the parties cannot obtain satisfactory warranties and acceptable contractual remedies, simply decline to play the game - captures a particular world view of lawyers and judges. It suggests a sharp divide between the world of the legal and the world of the everyday that perhaps lawyers and legal scholars perceive, but which seems to me self-deceptive or worse. What is a mistake is to assume that there is some kind of guild-like code, some special language, to which lawyers apply special magic to create precise rendition of the parties' complete agreement, apart from any common sense notions. ${ }^{89}$ Even more fundamentally, lawyers

\footnotetext{
${ }^{88}$ See AYRES \& KLASS, supra note 1, at 202.

${ }^{89}$ On the impact of social norms on the willingness to abide by legal rules or standards, see Yuval Feldman \& Alon Harel, Social Norms \& Ambiguity of Legal Norms: An Experimental Analysis of the Rule $v$. Standard Dilemma, available at http://ssrn.com/abstract=914164.
} 
bring to the table an "inflated 'rights consciousness' that disrupts more flexible and consensual extra-legal relationships." 90

The presumption of the divide between the everyday and the legal seems to me to be particularly lawyer-centric, and consistent with the way in which by licensing, language, and culture, lawyers continue to maintain they are "different." 91 Austin Sarat and Thomas Kearns have explored the everyday relationship to law, as against the way in which scholars analyze law. ${ }^{92}$ They criticize both instrumentalism - a sharp distinction between legal standards, on one hand, and non-legal human activity, on the other - and the constitutive view - that law shapes (and reflects) society by providing the categories and classification that make society seem coherent. ${ }^{93}$ In the deal context, legal instrumentalism would be the idea that the documents are the means (and one suspects the sole means) by which the deal gets done. Legal constitutivism would see the documents as the deal. Vice-Chancellor Strine's reflects a not-uncommon lawyer's constitutive view about the relationship of the contract language to reality itself: the purpose of the anti-reliance provision is to "define those representations of fact that formed the reality upon which the parties premised their decision to bargain."94

This is the epistemological center of the constitutive legal view: if you do not like a provision of the contract, you are entirely free to walk away. In castigating the Abry

\footnotetext{
${ }^{90}$ Mark C. Suchman \& Mia L. Cahill, The Hired Gun as a Facilitator: Lawyers and the Suppression of Business Disputes in Silicon Valley, 21 LAW \& Soc. INQUIRY 679, 680 (1996). The Suchman and Cahill thesis is that Silicon Valley lawyers are effective because they have managed to discard this attitude. ${ }^{91}$ This is hardly rigorous, but one of the ways that I could always be sure to grate on my non-lawyer colleagues in the corporation was to suggest that lawyers were different: that they needed to stick together in groups, rather than reside with the businesses, that their evaluation and compensation needed to be different, that their goals and objective were different.

${ }_{92}$ Austin Sarat \& Thomas R. Kearns, Beyond the Great Divide: Forms of Legal Scholarship and Everyday Life, in AUSTIN SARAT, ED., LAW IN EVERYDAY LIFE (1993).

${ }_{93} I d$., at 21-22.

${ }^{94} 891$ A.2d at 1058.
} 
buyer for its attempt to circumvent the anti-reliance clause, Vice-Chancellor Strine said, "The enforcement of non-reliance clauses recognizes that parties with free will should say no rather than lie in a contract." While this appeals to the Kantian in me, and might well be true in highly simplified models of contracting, it sells short the complex social structure that is a business acquisition. As Ayres and Klass recognize, even simple promises, much less large-scale deals, are complex communications. ${ }^{95}$ It is a conceit to believe either that lawyers are (or should be) capable of manipulating the parties' myriad understandings through language trickery, or that what they are doing in the drafting session constitutes the whole of the speech act that is the transaction. CEOs speak to CEOs; transition teams plan the integration of the businesses; pension experts value assets and projected liabilities; labor negotiators deal with unions and works councils; accountants and auditors work to create a pro forma set of financial statements for the business, environment experts do sampling and estimate remediation costs, sales and marketing personnel plot the way in which customers will be contacted. The reality (and not necessarily the contract-negotiating lawyer's perception) is that there is much of the everyday going on, and that everyday activity is no doubt just as critical to the required information-exchange in the transaction as what the lawyers are putting in the contract.

\section{(2) Contracts and Trust}

Sarat and Kearns propose instead a far more nuanced relationship between the law and everyday life, one in which attention to law is neither wholly explicit nor wholly ignored - a kind of legal shadow in the background influencing the way parties conduct

\footnotetext{
${ }^{95}$ AYRES \& KLASS, supra note 1, at 203.
} 
themselves. ${ }^{96}$ I suggest there is such a shadow in the law's incorporation of the everyday notion we do not lie to each other, even in contractual situations, and we do not deceive each other by parsing meanings so finely as to create half-truths. The law of fraud forms a kind of base condition, a safety net as it were, that makes concrete (even if it is rarely used) this moral notion..$^{97}$

If we proceed from a "state of nature" kind of model, why would a presumption of lying ever be the default state? Lawrence Friedman uses the example of Tristan de Cunha, a tiny and isolated island in the mid-Atlantic, as an organic society in which implicit norms of behavior never had to develop into explicit rules of law. ${ }^{98}$ Friedman suggests that while we continue to operate in our own small environs of Tristan de Cunha-like non-legal normativity, a dispersed and complex society develops law. It seems to me to invert how we develop to think that the language of the law would presume lying unless there is an express warranty of truth telling.

The law has had a long struggle with reconciling the tort and contract actions for misrepresentation; Vice Chancellor Strine recognized as much. ${ }^{99}$ Even at the height of the freedom of contract doctrine, there were still significant restrictions on caveat emptor, and the law of fraud as a separate action, even in a commercial context never

\footnotetext{
${ }^{96} \mathrm{Id}$., at 45 .

${ }^{97}$ See AYRES \& KLASS, supra note 1, at 202 ("[T] here is often a level of mistrust going into the transaction that makes it in the parties' mutual interest to have the representation backed by a legal guarantee."

${ }^{98}$ LAWRENCE M. FRIEDMAN, AMERICAN LAW (1984), at 31-33.

${ }^{99}$ The nature of that recognition is ironic, however. It comes in the context of construing whether the parties intended the word "misrepresentation" in the indemnity clause to include intentional as well as innocent misrepresentations. Vice-Chancellor Strine concluded they did, observing, "It is difficult to fathom why rational contracting parties would attempt to cut, by contract, a clear division that American jurisprudence has never been able to achieve: a division between the role of contract and tort law in addressing the consequences of false representations inducing the making and closing of contracts." 891 A.2d at 1054 .
} 
disappeared. ${ }^{100}$ Moreover, Anglo-American law bespeaks a rational and litigious culture in which consensus is less important than being right, so we try to reach the right answer, instead of working it out like the Europeans do. ${ }^{101}$ Lawyers are general more rational and formalistic than their clients, which is why there is never truly a caveat emptor business acquisition agreement. ${ }^{102}$

While in a simple model (the sale of wheat in a first-year contracts hypothetical) the contract may well constitute the reality of the deal (or model it so closely it is essentially the same thing), in a business acquisition, the contract sits within (and, indeed, perhaps at the center) of a far more complex web of trust and distrust relationship. It is simply disingenuous to think the essence of the deal is being captured solely by lawyers, with no other inter-subjective relationships. Recent work in the area of trust and the law is instructive. Francis Fukuyama has proposed a matrix on which to plot the way norms (including trust relationships) form - hierarchical versus spontaneous on one axis, and rational versus a-rational on the other. ${ }^{103}$ Economics itself is the discipline by which we

\footnotetext{
${ }^{100}$ P.S. ATIYAH, THE RISE AND FALL OF FrEEDOM OF CONTRACT (1979), at 388-98, 464-79.

${ }^{101}$ In German practice, the parties appear to be less opportunistic, not because they have managed to achieve a higher level of draftsmanship, but because the norm is simply to "stop sooner" in the process of customizing agreements. Claire A. Hill \& Christopher King, How Do German Contracts Do as Much with Fewer Words?, 69 CHI.-Kent L. REV. 889, 903 (2004) German parties adopt "good enough" provisions, apparently recognizing that agreeing on a tightly-drafted provision is not a reliable way of getting exactly what one wants in litigation anyway. Id., at 920-21.

${ }^{102}$ Suggesting a Gemeinschaft to Gesellschaft progression is beyond my scope here, but that also seems plausible to me. In his 1887 Gemeinschaft und Gesellschaft (Community and Society), Ferdinand Tönnies, the German sociologist and colleague of Max Weber, "developed the concepts of Gemeinschaft and Gesellschaft by elaborate analyses of their empirical prototypes: kinship, neighborhood, town and spiritual community are prototypes of the former; contractual relationships, collectives based on common interests, and special purpose associations are prototypes of the latter.... He saw the transition from a predominantly Gemeinschaft-like social order to a predominantly Gesellschaft-like social order primarily as a consequence of increasing commercialization together with the rise of modern state and the progress of science." Rudolf Heberle, Tönnies, Ferdinand, INTERNATIONAL ENCYCLOPEDIA OF THE SOCIAL SCIENCES, VOL. 16 (David Sills, ed.) (1968), 98-102. For a discussion of the development of the forms of trust as between primitive and modern societies, see Adam B. Seligman, Role Complexity, Risk, and the Emergence of Trust, 81 B.U. L. REV. 619, 620-24 (2001).

${ }^{103}$ Francis Fukuyama, Differing Disciplinary Perspectives on the Origins of Trust, 81 B.U. L. REV. 479 (2001). It is no coincidence that most of the following citations are to Volume 81 of the BOSTON
} 
study rational but spontaneously-generated norms. ${ }^{104}$ Yet Fukuyama is skeptical of a wholly rational approach to trust norms, and there is no reason to believe deal-makers are wholly rational actors. ${ }^{105}$

The contract may reflect the deal but it is not the deal. In their study of trusting and trustworthiness, Professors Ben-Ner and Putterman observed:

Especially when companies engage in business dealings with one another, there are typically small numbers of distinct individuals involved in the process, including managers who work out the terms, lawyers consulted on various details, and top executives who have to ratify any major transactions. Individuals place not only their company's, but their personal reputations for toughness, honesty, and so forth, on the line as they deal with one another on behalf of their companies. Telephone conversations, face-to-face meetings, and handshakes occur between flesh-and-blood individuals, and the usual cues of reliability--reliability, that is, of the individuals concerned-are evaluated to form estimates of whether the trading partner can be counted upon. ${ }^{106}$

Business people know intuitive that the contract will be incomplete, and resolving the many issues, for example, that pop up once a deal is closed will depend on some

UNIVERSITY LAW REVIEW. Issues 2 and 3 of that volume were devoted to a symposium on the subject of trust.

${ }^{104} I d$, at 487.

${ }^{105}$ Fukuyama concludes:

Today there is relatively little exchange and even less consensus across disciplinary lines concerning the question of norm genesis and trust. Those who believe that the social sciences can achieve a unified approach to the study of behavior tend to come out of the economics tradition. For the reasons outlined above, I am very skeptical that this kind of unity will ever be achieved. The social capital and trust relationships we see in the real world are highly complex outcomes that exhibit both emergent properties and path dependencies that were the products of long-forgotten initial conditions. A game theoretic approach yields many important insights into the circumstances in which norms and trust arise, and for that reason is highly useful to policy. But in other circumstances, we have to content ourselves not with analysis that is not "scientific," but rather ethnographic and descriptive in nature.

Id., at 493-94.

${ }^{106}$ Avner Ben-Ner and Louis Putterman, Trusting and Trustworthiness, 81 B.U. L. REV. 523, 539-40 (2001). 
modicum of mutual good faith. ${ }^{107}$ Whether one approaches the concept of trust from an economic perspective (i.e. that it serves to enhance efficiency by reducing the transaction costs of the creation and enforcement of contracts), ${ }^{108}$ or from, what is for me, a far more satisfying psychological, philosophical and ethical perspective, ${ }^{109}$ there seems to be no real debate that trust is, in the words of Professor Bainbridge, trust is a "lubricant to reduce social friction" $" 110$ in the deal context as much as any other.

Claire Hill and Erin O'Hara posit that the role of the law should be not necessarily to encourage or discourage trust, but to optimize it. ${ }^{111}$ Their thesis is that legal scholars assume trust to be wholly good or wholly bad, not recognizing or acknowledging that trust and distrust can co-exist in the same relationship. ${ }^{112}$ Accordingly, the law should create incentives to trust where more trust is beneficial, and discourage it where it is not. ${ }^{113}$ An example of concurrent trust and distrust in a relationship is that of corporate board to corporate management. Hill and O'Hara observe (correctly, I believe) that the

\footnotetext{
${ }^{107}$ While I would never have suggested that a major acquisition could be done on a handshake, I used to pose the question to clients to tell their resolve to complete a deal with this question: "if you could, would you do this deal on a handshake?" The question was a reflection of a shared understanding that neither the contract nor resort to the legal system was likely to be an effective way of resolving most post-closing issues.

${ }^{108}$ Larry E. Ribstein, Law v. Trust, 81 B.U. L. REV. 553 (2001).

${ }^{109}$ Lawrence E. Mitchell, The Importance of Being Trusted, 81 B.U. L. REV. 591 (2001). Professor Mitchell's essay is worth a full read in its own right, apart from its helpfulness as a citation here. He taps into the mystery of trust that transcends rational calculation, largely in response to Oliver Williamson's attempt to demonstrate that trust only exists in narrow areas of human life outside of the economic realm. Oliver Williamson, Calculativeness, Trust and Economic Organization, 36 J.L. \& EcON. 453 (1993). Mitchell's thesis is that for trust to have the instrumental value given to it in economic models, the capacity for trust must be deeply internalized in a way that economic modeling cannot explain. 81 B.U. L. REV. at 597. Trust in some respects is a matter of epistemology: "To trust is, as Niklaus Luhmann teaches us, to organize our world." Id., at 599.

${ }^{110}$ Stephen M. Bainbridge, Corporate Decision-Making and the Moral Rights of Employees: Participatory Management and Natural Law, 43 VILL. L. REV. 741, 789 (1998).

${ }^{111}$ Claire A. Hill \& Erin O'Hara, A Cognitive Theory of Trust, forthcoming, WASH.U.L.Q., currently available at http://ssrn.com/abstract $=869423$.

${ }^{112}$ Perhaps one of the most notable popular renditions of this theme was President Reagan's use of the Russian maxim "trust but verify" to characterize his attitude toward negotiating with Mikhail Gorbachev. See Ronald Reagan, Farewell Address to the Nation (Jan. 11, 1989), available at http://www.reaganfoundation.org/reagan/speeches/farewell.asp (last visited, Dec. 20, 2006).

${ }^{113}$ Hill \& O’Hara, supra note , at
} 
relationship of board to management is not wholly one of monitoring (implying distrust) nor of leadership and management (implying trust), and that regulatory incentives need to be fine-tuned so as not to sub-optimize either aspect. ${ }^{114}$

Both the process and the substance of making deals reflect this concurrent trust/distrust polarity. Parties regularly go forward with significant expenditures on nonbinding letters of intent. Lawyers cede drafting responsibilities, act as informal escrow agents with respect to in-process documents, or take each other's word. Indeed, as Ayres $\&$ Klass note, contract damages are notoriously under-compensating. ${ }^{115}$ Making a deal inherently means trusting the other party to some extent, because the legal remedies embodied in the contract will almost never equal the expectation value of the agreement. ${ }^{116}$ Or as Professor Seligman observed, "there is a connection between trust and risk." 117 Precisely because there is no viable legal remedy, trust mediates "the risk that is incurred when we cannot expect a return or reciprocal action on alter's part (which of course we could, at least within certain boundaries, when interaction is defined solely

\footnotetext{
${ }^{114} I d$., at .

${ }^{115}$ AYRES \& KLASS, supra note , at .

${ }^{116}$ William Sahlman, the dean of entrepreneurship scholars, has made the following observation about the relationship of contract language to deal-making:

Often, deal makers get very creative, crafting all sorts of payoff and option schemes. That usually backfires. My experience has proven again and again that sensible deals have the following six characteristics:

○ They are simple.

- They are fair.

- They emphasize trust rather than legal ties.

- They do not blow apart if actual differs slightly from plan.

- They do not provide incentives that will cause one or both parties to behave destructively.

- They are written on a pile of papers no greater than onequarter inch thick.

William A. Sahlman, How to Write a Great Business Plan, HARV. Bus. ReV. 98, 107 (July-Aug. 1997).

${ }^{117}$ Seligman, supra note , at 623.
} 
by the reciprocally defined nature of role obligations and commitments)." ${ }^{\prime 18}$ Trust is the completion of the incomplete contract. ${ }^{119}$

What then is the optimum default rule with respect to the construction of antireliance clauses? We can connect this exegesis on trust by returning to Professor Langevoort's discussion of half-truths. He proposes a sliding scale for half-truth liability. Where there is little or no trust between the parties, he concludes, it is difficult to justify the half-truth doctrine at all. But he leaves open how far the doctrine should operate in negotiations marked by a higher degree of trust. ${ }^{120}$ It seems to me clear: the volume of communication in the complex deal setting entails some significant level of trust, with, as Professor Langevoort puts it, "a broad half-truth doctrine, one with little privilege to conceal once a matter is addressed at all."121 It seems to me, then, barely a leap at all to my doctrinal result: any disclaimer that flies in the face of this trust must be narrowly construed.

\section{CONCLUSION}

The idea that the law governing business transactions should be wholly predictable and certain adopts a scientific world view, and does not map onto basic notions of either fairness or morality in every day life (as to which there is no evidence that deal lawyers or their clients have disclaimed). What makes us moral is making

${ }^{118} \mathrm{Id}$.

${ }^{119}$ Professor Seligman concludes:

Risk, as an aspect of social relations (no less than metaphysical doubt or mathematical probability) has emerged as a constitutive aspect of life in modern society and trust as a solution to this form of risk has, similarly, been its defining component.

Risk, I have endeavored to argue, became inherent to role-expectations when, with the transformation of social roles and the development of role-segmentation, there developed an in-built limit to systemically based expectations (what we have termed confidence) of

Id., at 633. role behavior.

${ }^{120}$ Langevoort, supra note , at 98.

${ }^{121} \mathrm{Id}$. 
choices and not knowing the outcome to a certainty (this is Kantian) and the law does a pretty good job of letting that happen, by building uncertainty into the system of resolution itself. Because the ultimate determination whether we made the right choice will be backward-looking and casuistic in every instance, determinations of good faith, fiduciary duty, fair dealing can never be algorithmic. The principles are predictable, and welfare-enhancing, only in the sense of there being some adoption of the rule of law but not in the algorithmic resolution of any individual case. ${ }^{122}$

Vice-Chancellor Strine made a valiant attempt but ultimately failed to draw the fine line in Abry (and recognized as much in a footnote of "intellectual candor"123). Courts need not be concerned that the world of commerce will collapse if the threat of a fraud claim hangs over deal participants, because the existence of some fraud remedy, even if the impact is somehow to go beyond the contractual representations, in fact reflects the way the parties do and should act. Accordingly, courts should give effect to disclaimers of truth-telling, but should presume they are exceptions to the default state, and hence construed as narrowly as possible.

\footnotetext{
${ }^{122}$ See F.A. HAYeK, THe ROAD TO SERFDOM (1944), at 80-96. I think it is this very subtle distinction that is at the heart of the Sarat and Kearns thesis about law as a shadow to everyday life, as well as Chancellor Allen's point about the ability of the Delaware corporate bench and bar to have "created the tools, the attitude and the very rich information that permit the moderate productive management of a system with great formal ambiguity. Allen, supra note 18, at 73.

${ }^{123} I d$., at 90 n.85.
} 


\section{Appendix A}

\begin{tabular}{|c|c|c|c|c|c|}
\hline & Contract Provisions & Fact Situation & Contract Outcome & Fraud Outcome Under Abry & Comment \\
\hline 1 & $\begin{array}{l}\text { "Company A does not have } \\
\text { any unionized facilities." } \\
\text { "There are no, and Buyer } \\
\text { disclaims any reliance on, } \\
\text { representations or } \\
\text { warranties, except those } \\
\text { expressly made in the } \\
\text { contract." }\end{array}$ & $\begin{array}{l}\text { A company official said during } \\
\text { due diligence that Company A } \\
\text { did have a unionized facility. } \\
\text { The company does have a } \\
\text { unionized facility. }\end{array}$ & $\begin{array}{l}\text { Buyer wins. Non-reliance } \\
\text { provision not relevant. Seller } \\
\text { wins only if the law or contract } \\
\text { imposes a rule under which } \\
\text { Buyer's knowledge of the falsity } \\
\text { of the representation from other } \\
\text { sources negates reliance. }\end{array}$ & $\begin{array}{l}\text { Unclear. Presumably the } \\
\text { knowing misrepresentation } \\
\text { element of fraud would be met, } \\
\text { but the non-contractual } \\
\text { disclosure should negate } \\
\text { reliance for purposes of fraud. }\end{array}$ & $\begin{array}{l}\text { If Buyer were to make a fraud } \\
\text { claim post- } A b r y \text {, why should } \\
\text { Seller get the benefit of a extra- } \\
\text { contractual disclosure to defeat } \\
\text { reliance? }\end{array}$ \\
\hline 2 & $\begin{array}{l}\text { Contract is silent on the } \\
\text { subject of unionization of } \\
\text { facilities. "There are no, and } \\
\text { Buyer disclaims any reliance } \\
\text { on, representations or } \\
\text { warranties, except those } \\
\text { expressly made in the } \\
\text { contract." }\end{array}$ & $\begin{array}{l}\text { Company A official during a } \\
\text { management presentation says } \\
\text { that Company A does not have } \\
\text { any unionized facilities. } \\
\text { The company does have a } \\
\text { unionized facility. }\end{array}$ & Seller wins. & $\begin{array}{l}\text { Seller wins. This is an } \\
\text { affirmative representation } \\
\text { outside the scope of the } \\
\text { agreement. }\end{array}$ & $\begin{array}{l}\text { This seems to be a fair case to } \\
\text { allow the operation of the non- } \\
\text { reliance clause. }\end{array}$ \\
\hline 3 & $\begin{array}{l}\text { "Company A does not have } \\
\text { any unionized facilities." } \\
\text { "There are no, and Buyer } \\
\text { disclaims any reliance on, } \\
\text { representations or } \\
\text { warranties, except those } \\
\text { expressly made in the } \\
\text { contract." }\end{array}$ & $\begin{array}{l}\text { There are no other non- } \\
\text { contractual representations, but } \\
\text { a senior official of Company A } \\
\text { knows that the workers at more } \\
\text { than one plant have approved } \\
\text { the formation of a union, but the } \\
\text { union election has not yet been } \\
\text { certified, and so technically the } \\
\text { company still does not have any } \\
\text { unionized facilities. }\end{array}$ & $\begin{array}{l}\text { The outcome will depend on the } \\
\text { interpretation of the word } \\
\text { "unionized." Was it intended to } \\
\text { include an approved but } \\
\text { uncertified union as well as } \\
\text { established unions? }\end{array}$ & $\begin{array}{l}\text { Unclear. If it is absolutely clear } \\
\text { to all concerned that "unionized } \\
\text { facilities" does not include one } \\
\text { in which the union has been } \\
\text { approved but the election has } \\
\text { not been certified by the NLRB, } \\
\text { then there can be no fraud, } \\
\text { because there is no untrue } \\
\text { statement. What is the } \\
\text { relationship of scienter to the } \\
\text { ambiguity of the original } \\
\text { representation? }\end{array}$ & $\begin{array}{l}\text { The example demonstrates the } \\
\text { possibility of a half-truth, even } \\
\text { in what would have seemed at } \\
\text { the outset to be a simple and } \\
\text { clear affirmative representation. } \\
\text { A laissez-faire approach would } \\
\text { place the burden on the Buyer to } \\
\text { obtain the correct information } \\
\text { by asking the correct question, } \\
\text { or to create express liability by } \\
\text { requiring the correct and } \\
\text { complete representation. }\end{array}$ \\
\hline
\end{tabular}




\begin{tabular}{|c|c|c|c|c|c|}
\hline & Contract Provisions & Fact Situation & Contract Outcome & Fraud Outcome Under Abry & Comment \\
\hline 4 & $\begin{array}{l}\text { Contract is silent on the } \\
\text { subject of unionization of } \\
\text { facilities. "There are no, and } \\
\text { Buyer disclaims any reliance } \\
\text { on, representations or } \\
\text { warranties, except those } \\
\text { expressly made in the } \\
\text { contract." }\end{array}$ & $\begin{array}{l}\text { During a management } \\
\text { presentation, Company A } \\
\text { official says "Company A does } \\
\text { not have any unionized } \\
\text { facilities" but knows that there is } \\
\text { an organizing campaign going } \\
\text { on in one of the plants. }\end{array}$ & Seller wins. & Seller wins. & $\begin{array}{l}\text { If an out and out lie is } \\
\text { disclaimed in Example 2, then a } \\
\text { half-truth, one supposes, is also } \\
\text { disclaimed. }\end{array}$ \\
\hline 5 & $\begin{array}{l}\text { "Company A's financial } \\
\text { statements fairly present in } \\
\text { all material respects the } \\
\text { financial condition of } \\
\text { Company on the dates and } \\
\text { for the periods presented in } \\
\text { accordance with generally } \\
\text { accepted accounting } \\
\text { principles consistently } \\
\text { applied." "There are no, and } \\
\text { Buyer disclaims any reliance } \\
\text { on, representations or } \\
\text { warranties, except those } \\
\text { expressly made in the } \\
\text { contract." }\end{array}$ & $\begin{array}{l}\text { Company A violated GAAP by } \\
\text { recognizing revenue out of cash } \\
\text { received from pre-paid } \\
\text { subscriptions. }\end{array}$ & $\begin{array}{l}\text { Buyer wins. Non-reliance } \\
\text { provision not relevant. }\end{array}$ & $\begin{array}{l}\text { Buyer wins. Presumably one } \\
\text { only misstates one's revenue } \\
\text { knowingly. }\end{array}$ & $\begin{array}{l}\text { What if Buyer has full access to } \\
\text { the financial records in due } \\
\text { diligence, but there is no "anti- } \\
\text { sandbag" clause? Same issue as } \\
\text { in Example } 1 . \\
\text { The point here is to show a } \\
\text { representation that is far more a } \\
\text { standard than a rule (in } \\
\text { contradistinction to the } \\
\text { representation on unionization.) }\end{array}$ \\
\hline
\end{tabular}




\begin{tabular}{|c|c|c|c|c|c|}
\hline & Contract Provisions & Fact Situation & Contract Outcome & Fraud Outcome Under $A b r y$ & Comment \\
\hline 6 & $\begin{array}{l}\text { "Company A's financial } \\
\text { statements fairly present in } \\
\text { all material respects the } \\
\text { financial condition of } \\
\text { Company on the dates and } \\
\text { for the periods presented in } \\
\text { accordance with generally } \\
\text { accepted accounting } \\
\text { principles consistently } \\
\text { applied." "There are no, and } \\
\text { Buyer disclaims any reliance } \\
\text { on, representations or } \\
\text { warranties, except those } \\
\text { expressly made in the } \\
\text { contract." }\end{array}$ & $\begin{array}{l}\text { Company A "stuffed the } \\
\text { channel." This means that it } \\
\text { caused its customers to buy } \\
\text { during Quarter 1, even though } \\
\text { the clear expectation was that } \\
\text { customers would not likely buy } \\
\text { during Quarter 2, after the sale } \\
\text { of the company. This practice } \\
\text { does not violate GAAP, and the } \\
\text { sales were in fact all made and } \\
\text { properly booked. } \\
\text { During due diligence, officers of } \\
\text { Company A expressly denied } \\
\text { the existence of channel } \\
\text { stuffing, but refused to give a } \\
\text { representation on it in the } \\
\text { contract, on the grounds that "it } \\
\text { is too hard to define." }\end{array}$ & $\begin{array}{l}\text { Unclear. How does one } \\
\text { interpret the GAAP standard? } \\
\text { For the periods in question, the } \\
\text { financial statements do accurate } \\
\text { present the financial condition. } \\
\text { So a strict constructionist (or } \\
\text { Seller) will argue that this is } \\
\text { literally true. The unstated is } \\
\text { that to the extent Buyer is } \\
\text { relying on one quarter to look } \\
\text { like the next (even accounting } \\
\text { for normal seasonal variation), } \\
\text { Seller knows it is creating a } \\
\text { mistaken impression. }\end{array}$ & $\begin{array}{l}\text { Presumably Seller wins because } \\
\text { as between a literalist } \\
\text { construction of the contract and } \\
\text { the fact that all the other } \\
\text { representations are extra- } \\
\text { contractual. }\end{array}$ & $\begin{array}{l}\text { Now the issue as between intra- } \\
\text { contractual and extra-contractual } \\
\text { representations and reliance is } \\
\text { not nearly as clear. } \\
\text { Does the original GAAP } \\
\text { representation create a partial } \\
\text { disclosure, the effect of which is } \\
\text { to create a duty of candor in the } \\
\text { due diligence? Does the burden } \\
\text { of disingenuousness fall on } \\
\text { Buyer or Seller? }\end{array}$ \\
\hline 7 & $\begin{array}{l}\text { "Company A's financial } \\
\text { statements fairly present in } \\
\text { all material respects the } \\
\text { financial condition of } \\
\text { Company on the dates and } \\
\text { for the periods presented in } \\
\text { accordance with generally } \\
\text { accepted accounting } \\
\text { principles consistently } \\
\text { applied." "There are no, and } \\
\text { Buyer disclaims any reliance } \\
\text { on, representations or } \\
\text { warranties, except those } \\
\text { expressly made in the } \\
\text { contract." }\end{array}$ & $\begin{array}{l}\text { Company A booked "return } \\
\text { reserves." The standard for } \\
\text { "return reserves" under GAAP } \\
\text { is that they must be based on a } \\
\text { reasonable estimate of expected } \\
\text { returns. The CFO issued a } \\
\text { memorandum to all controller } \\
\text { indicating that it was important } \\
\text { for the purpose of the impending } \\
\text { sale of the Company that all } \\
\text { return reserves be in accordance } \\
\text { with GAAP, but nevertheless err } \\
\text { on the side of low estimates } \\
\text { rather than high estimates. This } \\
\text { had the effect of making the } \\
\text { earnings look higher. Company } \\
\text { A deliberately did not disclose } \\
\text { this memorandum in due } \\
\text { diligence. }\end{array}$ & Seller wins. & $\begin{array}{l}\text { A strange outcome, but } \\
\text { presumably Seller wins, despite } \\
\text { the original sleazy practice of } \\
\text { pushing the envelope under the } \\
\text { broad strictures of GAAP and } \\
\text { the ensuing cover-up in due } \\
\text { diligence. }\end{array}$ & $\begin{array}{l}\text { Isn't the original representation } \\
\text { an assurance that Seller is not } \\
\text { playing games and telling half- } \\
\text { truth outside the contract? } \\
\text { If that is the case, why should } \\
\text { Buyer be limited to the remedy } \\
\text { inside the contract by the non- } \\
\text { reliance provision? }\end{array}$ \\
\hline
\end{tabular}


